\title{
A Betrayal of Trust? Back to the Drawing Board for Medical Manslaughter
}

The Journal of Criminal Law 202I, Vol. 85(5) 335-36I (C) The Author(s) 2021

Article reuse guidelines: sagepub.com/journals-permissions DOI: $10.1177 / 00220183211009319$

journals.sagepub.com/home/clj

@SAGE

\section{Jonathan Lilleker}

Teesside University, UK

\begin{abstract}
In seeking to provide a solution to the issues raised by medical manslaughter, Wheeler and Wheeler have recently proposed reform by way of a reconceptualised offence based on a breach of a fiduciary duty amounting to a betrayal of trust. This article provides an examination of gross negligence manslaughter, before undertaking a review of the proposals advocated by the authors. Applying the proposed offence to more contemporary cases than initially examined by Wheeler and Wheeler, namely, Misra and Srivastava, Kovvali, Rudling, Rose and Sellu, it is argued that despite the initial appeal of a betrayal of trust test, the proposals advocated by the authors do little to remedy the flaws within the current law.
\end{abstract}

\section{Keywords}

Medical manslaughter, gross negligence, betrayal of trust, culpability, moral blameworthiness

\section{Introduction}

In recent years, the appropriate legal response to death caused as a result of gross medical negligence has generated considerable academic debate. ${ }^{1}$ While it remains uncontroversial to assert that

1. M Brazier and N Allen, 'Criminalizing Medical Malpractice' in CA Erin and S Ost (eds), The Criminal Justice System and Health Care (OUP, Oxford 2007) 15-27; O Quick, 'Medical Killing: Need for a Specific Offence?' in CMV Clarkson and SR Cunningham (eds), Criminal Liability for Non-Aggressive Death (Routledge, Abingdon 2008) 155-75; O Quick, 'Medicine, Mistakes and Manslaughter: A Criminal Combination?' (2010) 69 CLJ 186; M Brazier, M Kazarian and D Griffiths, 'Criminal Responsibility for Medical Malpractice in France' (2011) 27 PN 188; D Griffiths and A Sanders, 'The Road to the Dock: Prosecution Decision Making in Medical Manslaughter Cases' in D Griffiths and A Sanders (eds), Bioethics, Medicine and the Criminal Law: Volume 2, Medicine, Crime and Society (CUP, Cambridge 2013) 117-58; D Archard, 'Criminalising Medical Negligence' in A Alghrani, R Bennett and S Ost (eds), Bioethics, Medicine and the Criminal Law: Volume 1, The Criminal Law and Bioethical Conflict: Walking the Tightrope (CUP, Cambridge 2013) 236-50; M Brazier and others, 'Improving Healthcare Through the Use of Medical Manslaughter? Facts, Fear the Future' (2016) 22 C Risk 88; Elizabeth Stuart-Cole, 'Medical Manslaughter: The Effect of Lay Findings of (Criminal) Gross Negligence on Professional Tribunals' (2018) 82 JCL 197; J

\section{Corresponding author:}

Jonathan Lilleker, Graduate Tutor, Teesside University, Borough Road, Tees Valley, Middlesbrough TSI 3BX, UK.

E-mail: J.Lilleker@tees.ac.uk 
physicians ought to be subject to the criminal law, a solution which properly reflects the blameworthiness of the errant clinician, yet does not afford medical professionals unwarranted protection, remains elusive. ${ }^{2}$

In order to provide a more nuanced approach to the criminalisation of fatal medical errors, academic commentators have sought to raise the threshold of criminal responsibility to subjective recklessness. ${ }^{3}$ Yet despite the commission of two independent reviews into gross negligence manslaughter within a medical setting, ${ }^{4}$ and the wealth of academic support for legal reform, the substantive law remains unsatisfactory.

A novel solution may exist in the form of a reconceptualised offence based on a breach of a fiduciary duty amounting to a betrayal of trust as recently proposed by Wheeler and Wheeler. ${ }^{5}$ Despite its potential, to date little analysis of this betrayal of trust test has been undertaken. This article will therefore provide an overview of the key flaws within gross negligence manslaughter, before undertaking an examination of the authors' proposals to determine whether their test ameliorates the issues that plague the current law. The merits of their approach will be examined, before the potential flaws within the test are detailed. As a result of this analysis, it will be argued that the new test cannot be employed as a means with which to successfully reform the current law.

\section{Gross Negligence Manslaughter Revisited}

At present, unintentional fatal clinical errors committed by doctors with varying degrees of culpability are encompassed by the unwieldy and unforgiving offence of gross negligence manslaughter. ${ }^{6}$ Criticised as amounting to little more than an 'emotionally satisfying way to exact retribution', 7 it is alleged that pursuing criminal sanctions against doctors who lack moral blame will result in the adoption of 'defensive medicine', and a shortage of practitioners in 'high-risk' specialities. ${ }^{8}$

As is known, to secure conviction for gross negligence manslaughter, the prosecution must establish five elements:

(a) the defendant owed an existing duty of care to the victim;

(b) the defendant negligently breached that duty of care;

(c) it was reasonably foreseeable that the breach of that duty gave rise to a serious and obvious risk of death;

(d) the breach of that duty caused the death of the victim;

(e) the circumstances of the breach were truly exceptionally bad and so reprehensible as to justify the conclusion that it amounted to gross negligence and required criminal sanction. ${ }^{9}$

Vaughan, O Quick and D Griffiths, 'Medical Manslaughter: Where Next?' (2018) 100 RCS Bull 251; Jo Samanta and Ash Samanta, 'Gross Negligence Manslaughter and the Delivery of Healthcare: A Time for Change?' (2019) 26 EJHL 389.

2. Quick, 'Medical Killing' (n 1) 156.

3. A McCall Smith, 'Criminal Negligence and the Incompetent Doctor' (1993) 1 Med L Rev 336, 349; Brazier and Allen (n 1) 27; Quick, 'Medicine, Mistakes and Manslaughter' (n 1) 203; Brazier, Kazarian and Griffiths (n 1) 199.

4. Department of Health, Gross Negligence Manslaughter in Healthcare: The Report of a Rapid Policy Review (Department of Health, 2018); General Medical Council, Independent Review of Gross Negligence Manslaughter and Culpable Homicide (General Medical Council, London 2019).

5. R Wheeler and R Wheeler, 'Betrayal of Trust in Medical Manslaughter' (2019) 83 JCL 489.

6. Quick, 'Medicine, Mistakes and Manslaughter' (n 1) 203.

7. RE Ferner and SE McDowell, 'Doctors Charged with Manslaughter in the Course of Medical Practice, 1795-2005: A Literature Review’ (2006) 99 J R Soc Med 309, 314.

8. AC Elias-Jones, 'Medical Manslaughter or Systems Failure?' (2004) 10 C Risk 29, 30.

9. $R v$ Rose [2017] EWCA Crim 1168 at [77]. 
The simplicity with which the law can be stated however belies the controversy surrounding the offence. Since its confirmation in Adomako, ${ }^{10}$ references to the civil law to determine the existence and standard of the duty of care have been subject to extensive scholarly criticism. ${ }^{11}$ However, in the sphere of medical manslaughter, it is well-established that a duty of care exists between a doctor and their patient, ${ }^{12}$ with the conduct of the doctor examined against that of the reasonably prudent professional. Consequently, the most significant issues in the present context are for the breach of the duty to be sufficiently gross as to be criminal, and to give rise to a serious and obvious risk of death.

In addressing when civil negligence will attract criminal punishment, defining what amounts to gross negligence has proved to be an illusory concept. ${ }^{13}$ Traditionally, when directing the jury as to when they could find a defendant guilty, a host of "vituperative epithets' ${ }^{14}$ were employed to describe the requisite degree of culpability. Among the litany of indiscriminate judicial pronouncements are assertions that the conduct of the defendant must be the result of 'gross ignorance', ${ }^{15}$ 'most criminal inattention, ${ }^{16}$ or 'gross and culpable rashness'. ${ }^{17}$ Although useful in stressing the need for something more than mere civil negligence, these early attempts at defining gross negligence are hardly insightful, ${ }^{18}$ adding to the absence of legal clarity. ${ }^{19}$

Acknowledging that recourse to merely descriptive terms ought to be avoided, ${ }^{20}$ in Bateman, Lord Hewart CJ simply stated that in order to be criminal, the conduct of the defendant must have gone 'beyond a mere matter of compensation', showing 'such disregard for the life and safety of others ... [to be] deserving [of] punishment'. ${ }^{21}$ Whether the conduct of the defendant reaches this threshold is a question for the jury. ${ }^{22}$ As recognised, the direction suffers from the flaw of 'circularity', ${ }^{23}$ with the result that the defendant is only held responsible where the jury are of the opinion that their conduct was criminal. Despite acknowledging this flaw, this formulation was nevertheless cited with approval by Lord Mackay in Adomako. ${ }^{24}$ The subject of sustained criticism, ${ }^{25}$ this classic formulation of the test for gross negligence has survived relatively unscathed, and in the absence of any linguistic alternatives, has been met with begrudging 'acceptance'. ${ }^{26}$

10. $R v$ Adomako [1995] 1 AC 171 at 187 , per Lord Mackay.

11. G Virgo, 'Reconstructing Manslaughter on Defective Foundations' (1995) 54 CLJ 14, 15; E Phillips, 'R v Adomako [1995] 1 AC 171: Is this the Final Word on Negligent Manslaughter?' (1995) 29 L Teacher 338, 342-43; K Oliphant, 'Manslaughter: Recklessness or Gross Negligence?' (1996) 6 KCLJ 149, 151-52; A Reed, 'Ex Turpi Causa and Gross Negligence Manslaughter' (2005) 69 JCL 132; J Herring and E Palser, 'The Duty of Care in Gross Negligence Manslaughter' [2007] Crim LR 24; C Crosby, 'Gross Negligence Manslaughter by Omission: The Emergence of a Good Samaritan Law?' (2018) 82 JCL 127.

12. $R v$ Bateman (1927) 19 Cr App R 8; Adomako (n 10); $R$ v Misra; $R$ v Srivastava [2004] EWCA Crim $2375 ; R v$ Garg (Sundhanshu) [2012] EWCA Crim 2520; $R$ v Kovvali [2013] EWCA Crim 1056; $R$ v Bawa-Garba [2016] EWCA Crim 1841; $R v$ Rudling [2016] EWCA Crim 741; $R$ v Sellu [2016] EWCA Crim 1716.

13. Tinline $v$ White Cross Insurance Association Ltd [1921] 3 KB 327 at 330.

14. Wilson v Brett (1843) $11 \mathrm{M} \& \mathrm{~W} 113$ at 116, per Rolfe B.

15. $R v$ Webb (1834) 1 Mood \& R 405 at 413 , per Lord Lyndhurst CB.

16. $R v$ Williamson (1807) 3 Car \& P 635, per Lord Ellenborough CJ.

17. $R v$ Long (1831) 4 C \& P 423 at 441 , per Bayley B.

18. Andrews v DPP [1937] AC 576 at 582.

19. PJT O'Hearn, 'Criminal Negligence: An Analysis in Depth-Part I' (1964) 7 CLQ 27, 29.

20. Bateman (n 12) 16.

21. Ibid 11-12.

22. Ibid 11.

23. Law Commission, Criminal Law: Involuntary Manslaughter-A Consultation Paper, CP 135 (1994) [3.36]; JC Smith, Smith \& Hogan Criminal Law (8th edn Butterworths, London 1996) 385.

24. Adomako (n 10) 187.

25. Virgo (n 11) 15-16; S Gardner, 'Manslaughter by Gross Negligence' (1995) 11 LQR 22; V Tadros, 'The Limits of Manslaughter' in CMV Clarkson and SR Cunningham (eds), Criminal Liability for Non-Aggressive Death (Routledge, Abingdon 2008) 49-50; SR Kyd, T Elliott and MA Walters, Clarkson and Keating Criminal Law: Texts and Materials (9th edn Sweet \& Maxwell, London 2017) [8-077]; D Ormerod and K Laird, Smith, Hogan and Ormerod's Criminal Law (15th edn OUP, Oxford 2018) 594

26. JR Spencer, 'Prosecuting Medical Professionals for Manslaughter' (2019) 2 Arch Rev 9. 
While doctors are not alone in being subject to this famously vague test, the lack of clarity provided by the law is central to the difficulties associated with prosecutions for medical manslaughter. ${ }^{27}$ Absent the need for subjective fault, ${ }^{28}$ jurors may adopt an especially punitive interpretation of gross negligence, subjecting the defendant to an exacting threshold of criminal responsibility. ${ }^{29}$ Despite the direction of Lord Mackay enabling 'all the circumstances' to be taken into account, with his Lordship later stressing that the presence of any potentially exculpatory factors are critical to any determination of guilt, ${ }^{30}$ in reality, systematic failures are given a short shrift, ${ }^{31}$ and regarded as "peripheral to the guilt or absence of guilt of [any doctor]' ${ }^{32}$ Focusing squarely on the culpability of the defendant doctor, gross negligence fails to properly take stock of the significant role that institutional failings play in the clinical performance of physicians. ${ }^{33}$ For the physician in the dock, the consequences of the imprecision within Lord Mackay's judgment are all too apparent. Whether they are held criminally responsible is ultimately contingent on the 'standards which juries expect from their medical service', ${ }^{34}$ and as a particularly grave crime, the vagaries within such an essential element of the offence cannot be defended. ${ }^{35}$

In failing to clarify when negligent clinical conduct will become criminal, the test is of scant assistance to those tasked with applying the law. As famously highlighted, 'gut instinct' is commonly employed by prosecutors to determine whether the conduct of the allegedly criminal doctor is bad enough to warrant punishment. ${ }^{36}$ Although the lack of clarity enables prosecutors to exercise their discretion to the benefit of doctors whose conduct is on the cusp of criminality, ${ }^{37}$ the uncertainty is detrimental to medico-legal advisors tasked with informing their client when any fatal clinical mistake may result in penal sanctions. ${ }^{38}$

In an attempt to guide juries, the judiciary have deployed a myriad of terms to describe gross negligence, in the absence of a definition. The result of this legal imprecision is such that the views of any expert witness instructed to provide evidence on the quality of any doctors conduct may differ widely. ${ }^{39}$ This is hardly surprising, as experts often rely on alternative formulations of what amounts to gross negligence, commonly utilising a 'Bolam-based test' ${ }^{40}$ As prosecutors often refuse to pursue

27. Sir R. Francis QC, Written Evidence-Health and Social Care Committee: Patient Safety and Gross Negligence Manslaughter in Healthcare Inquiry (GNM0007, 2018) <http://data.parliament.uk/writtenevidence/committeeevidence.svc/evidencedocu ment/health-and-social-care-committee/patient-safety-and-gross-negligence-manslaughter-in-healthcare/written/91808.pdf $>$ accessed 3 August 2020.

28. Attorney General's Reference (No 2 of 1999) [2000] QB 796 at 809.

29. C Elliott, 'Recent Developments in the English Law of Involuntary Manslaughter' (1995) 3 Eur J Crime Cr L Cr J $272,277$.

30. Lord Mackay of Clashfern, 'Involuntary Manslaughter in Relation to Patient Care' (1999) 39 Med Sci Law $277,279$.

31. LJ Donaldson, 'Shadow of the Law in Cases of Avoidable Harm' (2016) 355 BMJ i6268; A Samanta and J Samanta, 'Gross Negligence Manslaughter and Doctors: Ethical Concerns Following the case of Dr Bawa-Garba' (2019) 45 J Med Ethics 10 , 12; R Ameratunga and others, 'Criminalisation of Unintentional Error in Healthcare in the UK: A Perspective from New Zealand' (2019) 364 BMJ 1706.

32. Bawa-Garba $v$ The General Medical Council [2018] EWCA Civ 1879 at [74].

33. Francis QC (n 27).

34. Gardner (n 25) 25-26.

35. N Padfield, 'Manslaughter The Dilemma Facing the Law Reformer' (1995) 59 JCL 291, 296.

36. Quick, 'Medicine, Mistakes and Manslaughter' (n 1) 193.

37. Griffiths and Sanders (n 1) 145.

38. M Brazier and A Alghrani, 'Fatal Medical Malpractice and Criminal Liability' (2009) 25 PN 51, 57.

39. P McDonald, 'The Expert Medical Witness: The Good, the Bad and the Ugly' (2017) 8 Trends Urol Men's Health 29; D Griffiths and O Quick, Managing Medical Manslaughter Cases: Improving Efficiency and Transparency? (Law Research Paper Series, Bristol 2019) 21

40. O Quick, 'Medical Manslaughter and Expert Evidence: The Roles of Context and Character' in D Griffiths and A Sanders (eds), Bioethics, Medicine and the Criminal Law: Volume 2, Medicine, Crime and Society (Cambridge University Press, Cambridge 2013) 109-The Bolam test as modified by Bolitho, was that a doctor would not be responsible in civil law where their conduct did not fall below that 'accepted as proper by a responsible body of medical men', Bolam v Friern Hospital Management Committee [1957] 1 WLR 582 at 587, per Mc Nair J. Following the decision of the House of Lords in Bolitho $v$ 
charges without two independent experts verifying the criminality of the doctor's conduct, ${ }^{41}$ whether any physician faces criminal charges maybe contingent not on their culpability, but the language employed by the experts when evaluating their conduct. Given the weight attached to their views, it is also all too easy for the expert to overstep their role during the trial process, with the expert quickly becoming the ultimate arbiter of guilt. ${ }^{42}$

More recently, the test for grossness has been described as requiring the conduct of defendant to be 'truly exceptionally bad', ${ }^{43}$ with the trial judge tasked with guarding against the expert usurping the role of the jury. Critically, the reference to 'bad' does not introduce a requirement of subjective mens rea, or that the defendant possess any ill will towards their victim. Rather, the phrase is merely employed as a descriptive term to refer to the behaviour of the defendant. ${ }^{44}$ The expression, however, still fails to properly quantify the degree of negligence required to ground criminal punishment, ${ }^{45}$ as even small clinical errors committed by a caring physician may have 'truly bad consequences' ${ }^{46}$ Jurors are still being asked to consider the conduct of the defendant clinician having regard to their own personal standards, ${ }^{47}$ with the result that jurors are determining questions of law. ${ }^{48}$ Notwithstanding the need for the breach to be 'truly exceptionally bad', it is arguable that the well-documented criticisms ${ }^{49}$ directed at the compliance of gross negligence with Article 7(1) $\mathrm{ECHR}^{50}$ still remain. As a result, the phrase offers little comfort to those who have long called for the criminal law to provide greater communication to any prospective defendant regarding the criminality of their conduct.

This largely unfettered discretion afforded to the jury also stands in marked contrast to the manner in which mere negligence is determined. ${ }^{51}$ While expert medical evidence is no longer 'conclusive' of good practice, ${ }^{52}$ the threshold for judicial scrutiny of accepted conduct is pitched at a level which is hardly conducive to patient success. ${ }^{53}$ The behaviour of the clinician must be 'incapable of withstanding logical analysis', ${ }^{4}$ and a judge cannot hold a doctor liable simply where they 'prefer one body of opinion' over another. ${ }^{55}$ Although the courts are allegedly no longer willing to defer to the medical

City and Hackney Health Authority [1998] AC 232 at 243, the body of expert opinion relied upon must be now be 'capable of withstanding logical analysis'.

41. O Quick, 'Prosecuting “Gross” Medical Negligence: Manslaughter, Discretion, and the Crown Prosecution Service’ (2006) 33 J Law Soc 421, 446.

42. O Quick, 'Expert Evidence and Medical Manslaughter: Vagueness in Action' (2011) 38 J Law Soc 496, 501.

43. Sellu, (n 12) [152]; Bawa-Garba (n 12) [36].

44. AP Simester and others, Simester and Sullivan's Criminal Law Theory and Doctrine (7th edn Hart Publishing, Oxford 2019) 436.

45. Wheeler and Wheeler (n 5) 492.

46. General Medical Council, Report: Responses to the Call for Written evidence Submissions to Inform the Independent Review of Gross Negligence Manslaughter and Culpable Homicide (GMC 2019) A235 < https://www.gmc-uk.org/-/media/docu ments/written-evidence-report-for-review-into-gnmch_pdf-78762887.pdf> accessed 3 August 2020.

47. Health and Social Care Committee, Oral Evidence: Patient Safety Gross Negligence Manslaughter in Healthcare Inquiry (HC 1582, 2018) Q4 <http://data.parliament.uk/writtenevidence/committeeevidence.svc/evidencedocument/health-and-socialcare-committee/patient-safety-and-gross-negligence-manslaughter-in-healthcare/oral/91923.pdf> accessed 3 August 2020.

48. Ibid, at Q4.

49. B Fitzpatrick, 'Gross Negligence Manslaughter: Compatibility with European Convention on Human Rights Article 7' (2005) 69 JCL 1.

50. Convention for the Protection of Human Rights and Fundamental Freedoms (European Convention on Human Rights, as amended) (ECHR).

51. I am grateful to the anonymous reviewer for drawing this point to my attention.

52. Hucks $v$ Cole [1993] 4 Med LR 393 at 397, per Sachs LJ.

53. Dr S Fox QC, 'Bolam Is Dead. Long Live Bolam' (2019) 4 JIPL 213, 214.

54. Bolitho (n 40) 243, per Lord Browne-Wilkinson.

55. Maynard v West Midlands Regional Health Authority [1984] 1 WLR 634 at 638, per Lord Scarman; Sidaway v Board of Governors of the Bethlem Royal Hospital [1985] AC 871 at 895, per Lord Diplock; Bolitho (n 40), Bellarby v Worthing and Southlands Hospitals NHS Trust [2005] EWHC 2089 at [112]. For further discussion on the appropriateness of an alternative 'superiority approach', see R Mulheron, Principles of Tort Law (2nd edn CUP, Cambridge 2020) 365-66. 
profession, ${ }^{56}$ the true impact of Bolitho ${ }^{57}$ is hardly clear. ${ }^{58}$ Whether a doctor is merely negligent, is therefore largely at the discretion of expert medical opinion.

Given that gross clinical errors can harm 'public trust in the profession', ${ }^{59}$ it may be argued that it is only fitting that a jury should be tasked with determining whether a physician's negligence warrants criminal punishment. However, any meaningful evaluation of a clinician's duties can 'only' be undertaken by a 'fellow [doctor]' ${ }^{60}$ While a juror may regard the clinical errors of any physician as particularly gross, when viewed from a medical perspective, the failings of any doctor may be more easily understood. ${ }^{61}$ Rather than being based on the emotionally charged views of a juror, a finding that the conduct of a doctor is so gross as to be criminal ought to be grounded in sound clinical practice. Yet at present, any conviction owes as much to the culpability of the defendant, as to how a juror 'perceives' the expert relied upon. ${ }^{62}$ It is incongruous that when faced with competing expert evidence, a judge within a civil trial cannot simply choose one expert over another, yet where a criminal conviction is concerned, a jury may prefer the opinion of one expert as to the grossness of a doctor's conduct, and find that the defendant ought to be responsible, simply due to the colour of the expert's tie.

In light of the traditional arguments underpinning Bolam, ${ }^{63}$ the freedom afforded to jurors by the judicial reluctance to define gross negligence with any real 'precision, ${ }^{64}$ is even more surprising. In contrast to other professional disciplines, ${ }^{65}$ the judiciary were traditionally loathe to pass judgment on accepted medical treatment, ${ }^{66}$ with the technical nature of expert 'medical evidence' enabling physicians to 'set [their own] standard of care'. ${ }^{67}$ Bolam $^{68}$ prevents the court from embarking on an 'amateur assessment ${ }^{69}$ of a clinician's behaviour, with the Bolitho ${ }^{70}$ gloss, as traditionally interpreted, ensuring that judicial intervention into medical practice is limited to 'oversight' as opposed to 'interference'. ${ }^{71}$ By way of contrast, the lack of guidance provided by the test for gross negligence necessitates that a juror assume the role of a doctor, and perform the very such feats that have been relied upon by the courts as a means to defer to expert evidence. Clinical evidence can often obscure, as opposed to illuminate, the legal decision-making process, ${ }^{72}$ yet a juror tasked with assessing the criminality of a doctor's conduct must embark on this difficult task, with little more than Lord Mackay's tautological remarks to inform their decision.

With regard to the third element of the offence, as recently confirmed by the Court of Appeal, the requirement for the breach of duty to give rise to a 'serious and obvious risk of death' is 'objective and prospective'. ${ }^{73}$ Therefore, unless the reasonably competent clinician with the knowledge possessed by

56. Lord Woolf, 'Are the Courts Excessively deferential to the Medical Profession?' (2001) 9 Med L Rev 1, 9-10.

57. Bolitho (n 40).

58. A Maclean, 'Beyond Bolam And Bolitho' (2002) 5 Med L Int 205; R Mulheron, 'Trumping "Bolam”: A Critical Legal Analysis Of Bolitho's "Gloss”, (2010) 69 CLJ 609.

59. S Ost, 'The Medical Profession as Special Before the Criminal Law' in I Bogg and others (eds), Criminality at Work (OUP, Oxford 2020) 298.

60. J Holyoak, 'Negligence and the Professions' in R Hodgin (ed), Professional Liability: Law and Insurance (2nd edn Informa Law, Abingdon 1999) 75.

61. J Larkin, 'Doctors, Negligence and the GMC' (2018) 63 Scott Med J 35, 36.

62. Quick (n 42) 516.

63. Bolam (n 40).

64. Adomako (n 10).

65. Edward Wong Finance Co Ltd v Johnson Stokes \& Master [1984] AC 296.

66. H Teff, 'The Standard of Care in Medical Negligence-Moving on from Bolam?' (1998) 18 OJLS 473, 476.

67. E Jackson, Medical Law: Text, Cases, and Materials (5th edn OUP, Oxford 2019) 132-33.

68. Bolam (n 40).

69. J Herring, Medical Law and Ethics (8th edn OUP, Oxford 2020) 138.

70. Bolitho (n 40).

71. N Hoppe and J Miola, Medical Law and Medical Ethics (CUP, Cambridge 2014) 56.

72. Boustead v North West Strategic Health Authority [2008] EWHC 2375 at [9] per MacKay J.

73. Rose (n 9) [78]. 
the defendant at the time of the breach would have foreseen the risk of death, the court is not permitted to take into consideration such matters when addressing 'either the foreseeability of risk, or the grossness of the conduct in question'. ${ }^{74}$ As opposed to merely considering whether the defendant's failure to possess knowledge which they ought to have had renders them culpable, this interpretation has been welcomed by Stark as enabling far greater scrutiny of the 'defendant's actual beliefs (and lack of thereof)' to be undertaken. ${ }^{75}$ This permits a more sophisticated assessment of their blameworthiness and attitude towards 'the risk of death' ${ }^{76}$ In the context of Rose ${ }^{77}$ when presented with two physicians, one who has omitted to undertake a compulsory procedure, and one who has performed it, yet failed to recognise the 'serious and obvious risk of death' arising from it, Stark argues that it is the latter who merits criminal punishment. ${ }^{78}$ This is because, they are the 'closest to possessing the belief that there was a serious risk of death attendant upon [their] breach'. ${ }^{79}$ Although this is contrary to our initial feelings of blame, ${ }^{80}$ for Stark the current formulation of gross negligence ensures that only those who are 'personally culpable with regard to the death [that their] act caused' are criminalised. ${ }^{81}$

However, in light of their failure to recognise the risks within their conduct, Stark's claim is questionable. While the opportunity to recognise a risk is present, for the doctor whose failure to identify a risk is attributable to an incompetent attempt at fulfilling their clinical duties, they are in fact further away from recognising the risks associated with their conduct than one who made no attempt whatsoever. This is due to the fact that in seeking to carry out what they considered was required of them at the time of their alleged negligence, a doctor's false assessment of the extent of their duty clouds their professional judgment, leading them to close their mind to the presence of obvious risks. ${ }^{82}$ A clear example is Dr Adomako. In wrongly concluding that his patient had stopped breathing due to an equipment fault, or the patient suffering an ocular cardiac reflex, ${ }^{83}$ he closed his mind to the possibility that the endotracheal tube had become detached. In seeking to administer what he considered was appropriate care, his preoccupation with remedying the drop in his patient's pulse and blood pressure inhibited his judgment, and his ability to consider what was arguably the most 'obvious' cause of the patient's struggles. ${ }^{84}$ It may therefore be asserted that rather than Dr Adomako, it is the anaesthetist who does not bother to respond at all to the patient who is not breathing, that is 'closest to possessing the belief that there was a serious risk of death attendant upon [their] breach'. If they had cared to look, they would have been better placed to identify the true source of their patient's struggles, as they would not have been preoccupied with extraneous matters. It is therefore submitted that Stark has mistakenly conflated the physical steps that are consistent with having the opportunity to possess knowledge of risks with actual mental awareness of risks, and Rose ${ }^{85}$ does not restrict criminal punishment to those who are sufficiently blameworthy.

In adopting an objective and prospective test, $\operatorname{Rose}^{86}$ ultimately shifts the balance of criminal responsibility in favour of the defendant ${ }^{87}$ who makes no attempt to fulfil their duty of care. ${ }^{88}$ This may be

74. Ibid.

75. F Stark, 'In Praise of Rose' (2019) 8 Arch Rev 7, 8.

76. Ibid.

77. Rose (n 9).

78. Stark (n 75) 8-9.

79. Ibid 8-9.

80. C Crosby, 'Gross Negligence Manslaughter Revisited: Time for a Change of Direction?' (2020) 84 JCL $228,244$.

81. Stark (n 75) 9.

82. This point was helpfully highlighted to me by Dr Cath Crosby.

83. Adomako (n 10) 182.

84. Ibid 181.

85. Rose (n 9).

86. Ibid.

87. M Gibson and A Reed, 'Reforming English Homicide Law: Fair Labelling Questions and Comparative Answers' in A Reed and others (eds), Homicide in Criminal Law: A Research Companion (Routledge, Abingdon 2019) 52.

88. K Laird, 'The Evolution of Gross Negligence Manslaughter' (2018) 1 Arch Rev 6, 8. 
considered a medicalisation of the law, ${ }^{89}$ which casts doubt on the true breadth of the offence. As gross negligence does not consider why the defendant failed to spot the risks inherent within their behaviour, the caring physician who attempts to fulfil their duty of care, yet due to their own personal inadequacies fails to identify a risk which results in the death of the patient, will face criminal responsibility. ${ }^{90}$ On the other hand, absent 'wilful blindness' the clinician who makes no effort to fulfil their duty will avoid criminal punishment. ${ }^{91}{ }^{1}$ ose $e^{92}$ therefore creates a 'perverse incentive for those who owe a duty of care to another to do as little as possible to discharge it' ${ }^{93}$ While it is doubtful whether any clinician would willingly offer substandard care in an effort to avoid criminal liability, ${ }^{94}$ given the alleged rise of defensive medicine, ${ }^{95}$ such claims cannot be completely dismissed. In ascribing criminal responsibility to physicians who lack moral blame, while equally exculpating those whose conduct evinces sufficient bad character to warrant punishment, ${ }^{96}$ the test of gross negligence may therefore be criticised for failing to criminalise culpable clinical errors.

\section{Moral Luck and Fair Labelling}

In addition to the criticisms levied at the elements of the offence, the crime has equally been condemned for the manner in which it infringes the principle of fair labelling, ${ }^{97}$ with the significant role afforded to 'moral luck' by prosecutions also coming under scrutiny. ${ }^{98}$

'Representative labelling, 99 more commonly known as 'fair labelling', 100 'is one of the guiding principles that should underpin the criminal law'. ${ }^{101}$ In short, any offence label ought to properly reflect the culpability of the defendant, and commonly held 'degrees of wrongdoing'. ${ }^{102}$ The criminal law is one of the most 'coercive tool[s] [of] the state', ${ }^{103}$ and given the unique stigma that flows from a criminal prosecution, ${ }^{104}$ namely the possibility for prejudice within both a social and professional setting, ${ }^{105}$ adherence is necessary to prevent the defendant from being subject to a greater degree of criticism than warranted. ${ }^{106}$ Mediating any unfairness towards the defendant, compliance with fair labelling may be considered part of the wider principle of 'respect and dignity'. ${ }^{107}$

\footnotetext{
89. Wheeler and Wheeler (n 5) 501.

90. Crosby (n 80).

91. A Mullock, 'Gross Negligence (Medical) Manslaughter and the Puzzling Implications of Negligent Ignorance: Rose v R [2017] EWCA Crim 1168' (2018) 26 Med L Rev 346, 353-54.
}

92. Rose (n 9).

93. Laird (n 88).

94. Ibid 8-9.

95. O Ortashi and others, 'The Practice of Defensive Medicine Among Hospital Doctors in the United Kingdom' (2013) 14 BMC Med Ethics 42; J Vaughan, 'Gross Negligence Manslaughter and the Healthcare Professional' (2016) 98 RCS Bull 60, 62.

96. Crosby (n 80) 243-44.

97. Quick, 'Medical Killing' (n 1) 159; Quick, 'Medicine, Mistakes and Manslaughter' (n 1) 203.

98. Brazier and Allen (n 1) 21-22; Quick, 'Medicine, Mistakes and Manslaughter' (n 1) 203; Griffiths and Sanders (n 1) $126-27$.

99. A Ashworth, 'The Elasticity of Mens Rea' in CFH Tapper (ed), Crime, Proof and Punishment: Essays in Memory of Sir Rupert Cross (Butterworths, London 1981) 53.

100. G Williams, 'Convictions and Fair Labelling' (1983) 42 CLJ 85; S. Shute, J Gardner and J Horder, 'The Logic of Criminal Law' in S Shute, J Gardner and J Horder (eds), Action and Value in Criminal Law (OUP, Oxford 1993) 9.

101. CMV Clarkson, Understanding Criminal Law (4th edn Sweet \& Maxwell, London 2005) 10.

102. A Ashworth and J Horder, Principles of Criminal Law (7th edn OUP, Oxford 2013) 77.

103. V Tadros, Criminal Responsibility (OUP, Oxford 2005) 1.

104. AF Merry, 'When Are Errors a Crime?-Lessons from New Zealand' in CA Erin and S Ost (eds), The Criminal Justice System and Health Care (OUP, Oxford 2007) 69.

105. V Tadros, 'Fair Labelling and Social Solidarity' in L Zedner and JV Roberts (eds), Principles and Values in Criminal Law and Criminal Justice: Essays in Honour of Andrew Ashworth (OUP, Oxford, 2012) 70-71.

106. HM Zawati, Fair Labelling and the Dilemma of Prosecuting Gender-Based Crimes at the International Criminal Tribunals (OUP, Oxford 2014) 30.

107. A Ashworth, 'Towards a Theory of Criminal Legislation' (1989) 1 Crim LF 41, 45. 
In seeking to secure these aims, it is clear that fair labelling cannot require an 'extreme' approach, whereby every moral distinction and factual circumstance is reflected in the offence label. ${ }^{108}$ Rather, a 'balance' between 'excessively specific labels' and those which are so vague as to be devoid of any communicative role must be struck. ${ }^{109}$ This is critical not only to avoid succumbing to the "vice of particularism ${ }^{110}$ but also to ensure compliance with the principle of minimal criminalisation. ${ }^{111}$ However, in relation to gross negligence, the balance currently struck cannot be defended. ${ }^{12}$ At present, although a defendant need not personally foresee a risk of harm, foresight of death or serious injury may nevertheless be evidence that the defendant was grossly negligent. ${ }^{113}$ Therefore, in addition to the truly inadvertent killer, the offence captures those who 'have foreseen a risk', yet were nevertheless 'determined to run it' ${ }^{114}$

This is no more apparent than in the criminal conviction of $M c G e e .{ }^{115}$ In signalling for the train to depart the platform while 'watching [the victim] leaning against the side of the train', ${ }^{116}$ McGee surely possessed awareness of the risks posed by his conduct. Yet despite the presence of a clear and obvious 'risk to the life of [Georgia Varley]', McGee 'completely ignored [his] repeated training and instruction'. ${ }^{117}$ Moreover, in contrast to Dr Adomako's mistaken efforts to remedy his incompetence, ${ }^{118}$ McGee made no attempt whatsoever to 'countermand' his actions. ${ }^{119}$ This is notwithstanding the ease of taking such steps to "signal the driver to stop'. ${ }^{120}$ As with Doctors Misra and Srivastava, ${ }^{121}$ McGee is arguably deserving of a reckless manslaughter conviction. However, due to the breadth of the crime, his actions are caught by the gross negligence framework. The offence consequently encompasses an especially wide class of defendants, ${ }^{122}$ with the result that when the manslaughter label is applied in cases of death caused by clinical gross negligence, it is questionable as to what the term truly implies about the conduct and culpability of the accused. ${ }^{123}$

Although similar criticisms may be raised at other offences within the homicide ladder, ${ }^{124}$ where it is the manner in which the defendant has undertaken a lawful act which renders them criminal, it is imperative that the offence truly encapsulates the harm committed, and the way in which it was brought about. When regard is had to the benefits that flow from medicine, this argument assumes greater persuasive force, as not only are the consensually performed actions of a doctor lawful, but they are clearly desirable. Any offence that criminalises poor medical treatment ought to therefore

108. B Mitchell, 'Multiple Wrongdoing and Offence Structure: A Plea for Consistency and Fair Labelling' (2001) 64 MLR 393, 399.

109. AP Simester and A Von Hirsch, Crimes, Harms and Wrongs: On the Principles of Criminalisation (Hart Publishing, Oxford 2011) 205.

110. J Horder, 'Rethinking Non-Fatal Offences Against the Person' (1994) 14 OJLS 335, 339.

111. Clarkson (n 101) 10-11.

112. Quick, 'Medicine, Mistakes and Manslaughter' (n 1) 200.

113. Attorney General's Reference (No 2 of 1999) [2000] QB 796 at 809.

114. $R v$ Stone; $R v$ Dobinson [1977] QB 354 at 363, per Geoffrey Lane LJ.

115. $R v$ Christopher James McGee (Unreported), Liverpool Crown Court, 15 November 2012. Christopher James McGee, a train guard, was found guilty of gross negligence manslaughter for the death of Georgia Varley, after he signalled for the train to depart the station while Varley was 'leaning against the side of the train'. $R v$ McGee (15 November 2012), Sentencing remarks of Mr Justice Holroyde, p $3<$ https://www.judiciary.uk/wp-content/uploads/JCO/Documents/Judgments/sentencingremarks-mr-j-holroyde-r-v-mcgee.pdf $>$ accessed 15 February 2021.

116. Sentencing remarks of Mr Justice Holroyde (n 115).

117. Ibid 3-4.

118. Adomako (n 10) 182.

119. Sentencing remarks of Mr Justice Holroyde (n 115).

120. Ibid.

121. Misra and Srivastava (n 12).

122. A Lodge, 'Gross Negligence Manslaughter on the Cusp: The Unprincipled Privileging of Harm over Culpability’ (2017) 81 JCL 125 at 131.

123. A Merry and W Brookbanks, Merry and McCall Smith's Errors, Medicine and the Law (2nd edn CUP, Cambridge 2017 ) 310.

124. Gibson and Reed (n 87) 40. 
clearly provide both the public and the defendant doctor with a true indication of their culpability, and why they have been held responsible. At present, the label 'gross negligence manslaughter' does neither.

As to 'moral luck', where the negligence of two clinicians is the same, yet due to fortuitous circumstances, only one causes death, the lack of any general offence of gross negligence endangering life is such that the clinician who avoids causing death will not face criminal sanctions. ${ }^{125}$ This results in the offence being 'an unsatisfactory "all or nothing" scenario', ${ }^{126}$ with the 'lucky' doctor benefiting from the 'fortuitous gap' in punishment. ${ }^{127}$ To strict subjectivists, the weight attached to the outcome of death detracts from our inquiry into the blame of any criminal agent and has little bearing on their 'moral blameworthiness'. ${ }^{128}$ Death may be a matter beyond the control of an agent, and to only impose punishment on the actor who causes death is to attach weight to matters of 'moral luck', which is contrary to 'Kantian traditions of fairness'. 129

Although such concerns are hardly unique to gross negligence manslaughter, ${ }^{130}$ within the sphere of medicine, the mere fact that a patient has died cannot be regarded as increasing the moral culpability of any clinician. ${ }^{131}$ The denunciatory nature of penal sanctions is such that they ought to be applied for 'wrongs not misfortunes', ${ }^{132}$ and not results influenced largely by chance. In addressing the criminal response to clinical errors, our focus ought to be on 'the actual behaviour' of the errant doctor. ${ }^{133}$ Where the conduct of the clinician demonstrates indifference to the welfare of their patient, to restrict criminal punishment to fatal medical errors cannot be defended.

It must be acknowledged that where a clinician is alert to the need to provide care, yet 'deliberately' avoids doing so, ${ }^{134}$ or abstains due to the fact that they '[did not care] whether action was required or not', ${ }^{135}$ a prosecution for wilful neglect may follow. ${ }^{136}$ This offence may be charged even where no harm to the patient materialises. By ensuring that the reckless clinician does not avoid criminal charges merely due to the fact that the death of their patient is averted, the crime of wilful neglect may be regarded as mitigating the influence of moral luck. ${ }^{137}$ However, in discounting grossly negligent harm short of death, for the truly inadvertent physician, the only option is a prosecution for gross negligence manslaughter, or no criminal sanction whatsoever. Consequently, the role of moral luck is arguably heightened, with the result that criminal prosecution is even more of an unsatisfactory lottery than prior to the introduction of the offence. Furthermore, as Kazarian notes, should the death be influenced by systematic errors, in necessitating a higher threshold of criminality for wilful neglect than homicide, the inconsistent approach created by the two crimes can hardly be considered just. ${ }^{138}$

125. Brazier and Allen (n 1) 21-22; Griffiths and Sanders (n 1) 126-27; M Brazier and S Ost, 'From Theatre to the Dock-Via the Mortuary' in M Brazier and S Ost (eds), Bioethics, Medicine and the Criminal Law: Volume 3, Medicine and Bioethics in the Theatre of the Criminal Process (CUP, Cambridge 2013) 79-80.

126. Quick, 'Medicine, Mistakes and Manslaughter' (n 1).

127. Y Shachar, 'The Fortuitous Gap in Law and Morality' (1987) 6 Crim Just Ethics 12.

128. A Ashworth, 'Taking the Consequences' in S Shute, J Gardner and J Horder (eds), Action and Value in Criminal Law (OUP, Oxford 1993) 110.

129. G Sher, 'Kantian Fairness' (2005) 15 Philos Issues 179.

130. $R$ v Creamer [1966] 1 QB 72 at 82.

131. Brazier and Allen (n 1) 22.

132. Ashworth (n 128) 120.

133. D Hubbeling, 'Medical Error and Moral Luck' (2016) 28 HEC Forum 229, 231.

134. $R v$ Patel [2013] EWCA Crim 965 at 40, per Jackson LJ.

135. $R v$ Turbill [2013] EWCA Crim 1422 at [12], per Hallett LJ.

136. Criminal Justice and Courts Act 2015, s 20(1).

137. M Kazarian, 'Who Should We Blame for Healthcare Failings? Lessons from the French Tainted Blood Scandal' (2019) 27 Med L Rev 390, 399.

138. Ibid 399-400. 
This unfairness may have been remedied by the decision in Rose, ${ }^{139}$ which has been argued as necessitating that 'the defendant knowingly [took] a risk with the victim's life'. ${ }^{140}$ In adopting a subjective threshold of liability, it may be asserted that the Court of Appeal has indirectly harmonised the fault threshold for gross negligence with that of wilful neglect. Should a doctor have knowledge that a particular form of treatment was required, or have had sight of the patient's notes, yet 'deliberately ignored' the information, their conduct may properly be regarded as reckless and thus attract punishment for wilful neglect. Should death occur, the Rose ${ }^{141}$ foreseeability requirements would also clearly be met, with the result that conviction for gross negligence manslaughter could equally follow, potentially resolving the inconsistency identified above.

Having analysed the deficiencies inherent in the gross negligence manslaughter offence, the focus will now move to consideration of the proposed alternative, betrayal of trust, as advanced by Wheeler and Wheeler.

\section{A Betrayal of Trust}

Wheeler and Wheeler assert that legal reform is necessary to properly determine when culpable medical errors warrant criminalisation. Following Rose, ${ }^{142}$ the authors propose a test based on a 'fiduciary duty' and 'betrayal of trust'. Accordingly, a doctor would be criminally responsible where:

(a) the defendant owed a fiduciary duty to the victim;

(b) the defendant breached that duty in a way that amounted to a betrayal of trust;

(c) it was reasonably foreseeable that the breach of that duty gave rise to a serious and obvious risk of death;

(d) the breach of that duty caused the death of the victim. ${ }^{143}$

At first glance, a test based on a fiduciary duty and a betrayal of trust is appealing. Despite the lack of domestic authority confirming that doctors owe their patient a fiduciary duty, it is axiomatic that the 'hallmarks of a fiduciary relationship' ${ }^{144}$ are present between a physician and their patient. ${ }^{145}$ The Good Medical Practice guidance notes that any healthcare professional must 'make the care of [their] patient [their] first concern' and 'work with colleagues in the ways that best serve [their] patients' interests'. ${ }^{146}$ It is therefore profoundly clear that a clinician should 'never betray [their] patients' trust' nor act in a manner that is contrary to their 'best interests'. ${ }^{147}$

In addition to providing evidence of the fiduciary relationship, such qualities may also be considered "character standards ${ }^{148}$ which are intrinsic to the role of a doctor, and provide a baseline standard of proper clinical care. In considering the exculpatory scope of the criminal law, Gardner has previously noted how an agent ought to be subject to criminal punishment where their conduct fell below the

139. Rose (n 9).

140. Mullock (n 91) 354-55.

141. Rose (n 9).

142. Ibid.

143. Wheeler and Wheeler (n 5) 492.

144. Norberg v Wynrib [1992] 2 SCR 226, 272, per McLachlin J.

145. P Bartlett, 'Doctors as Fiduciaries: Equitable Regulation of the Doctor-Patient Relationship' (1997) 5 Med L Rev 193, 194; JCP Goldberg and BC Zipursky, 'Triangular Torts and Fiduciary Duties' in PB Miller and AS Gold (eds), Contract, Status, and Fiduciary Law (OUP, Oxford 2016) 246; S Ost, 'Breaching the Sexual Boundaries in the Doctor-Patient Relationship: Should English Law Recognise Fiduciary Duties?’ (2016) 24 Med L Rev 206, 224.

146. General Medical Council, Good Medical Practice: Working with Doctors Working for Patients (GMC, Manchester 2014).

147. Wheeler and Wheeler (n 5) 493.

148. J Gardner, 'The Gist of Excuses' (1998) 1 Buff Crim LR 575. 
'normative expectations' demanded of them by their 'role'. ${ }^{149}$ Consequently, a doctor whose gross negligence causes the death of their patient warrants criminal punishment, as in failing to meet the standards of the reasonably competent physician, their behaviour demonstrates that they lack the necessary character traits and competence for the position. Controversially, for Gardner, where the conduct in question falls far below that required by their role, a lack of capacity to meet 'normative expectations' will not exculpate, it merely confirms their lack of suitability for the role. ${ }^{150}$ If this is applied to Doctors Prentice and Sullman, despite their lack of training and proper supervision while performing the procedure, ${ }^{151}$ their fatal injection of vincristine intrathecally, rather than intravenously, would render them both the appropriate subjects of punishment.

Given that their negligence was largely the result of institutional errors, ${ }^{152}$ as opposed to individual mistakes, that Gardner's test would inculpate both doctors demonstrates how isolated focus on the role of the defendant as a means to determine their culpability produces an excessively harsh result. In order to prevent excessive criminality, consideration ought to be given not only to an agent's role, but the extent to which their failure to comply with the standards demanded of them demonstrates 'vice'. ${ }^{153}$ However, as opposed to indifference, the conduct of Doctors Prentice and Sullman epitomises the paradigm of excusable fatal clinical errors.

While Dr Prentice expressed concern at administering the vincristine, demonstrating awareness of his own professional limitations, he only agreed to perform the procedure under supervision. ${ }^{154}$ Rather than being insufficiently motivated by the interests of his patient, this demonstrates that he sought to avoid any potential harm caused by his inexperience. Although the failure to check the drug label may appear to be an elementary error, given his mistaken belief as to the degree of supervision that was being performed by Dr Sullman, ${ }^{155}$ the fact that Sullman personally 'handed [both] syringes [to him]', ${ }^{156}$ and his lack of knowledge of the drastic consequences should vincristine be injected intrathecally, ${ }^{157}$ it is arguable that he would have given no thought to the possibility of taking such precautions. Rather, it is likely that he would have acted under the mistaken belief that should his conduct expose the patient to any risk, he would have been stopped prior to injecting the drug. As such it is clear that Dr Prentice took all the necessary steps that he considered necessary to safely deliver the medication.

As to Dr Sullman, due to his mistaken belief as to the true extent of his supervisory role, ${ }^{158}$ it is arguable that he formed a wrongful belief as to the possibility that Dr Prentice may administer the drug in the incorrect way. Critically, given his unawareness of what was required of him in the circumstances, ${ }_{159}$ the formation of this belief is one which is neither unreasonable nor attributable to any culpable prior choice. While both doctors ought to have ensured that they fully understood the nature of their respective roles, and the limits of their combined expertise, poor communication skills can hardly be regarded as a vice worthy of penal sanctions. Fittingly, Wheeler and Wheeler would exculpate errors attributable to 'inadequate training, ${ }^{160}$ thus rejecting strict conformity with Gardner's model. However, a betrayal of trust manifested through conduct which is contrary to the best interests of any patient is arguably the clearest indication that a doctor has acted inconsistently with the 'normative expectations' of their role, making a jury likely to convict.

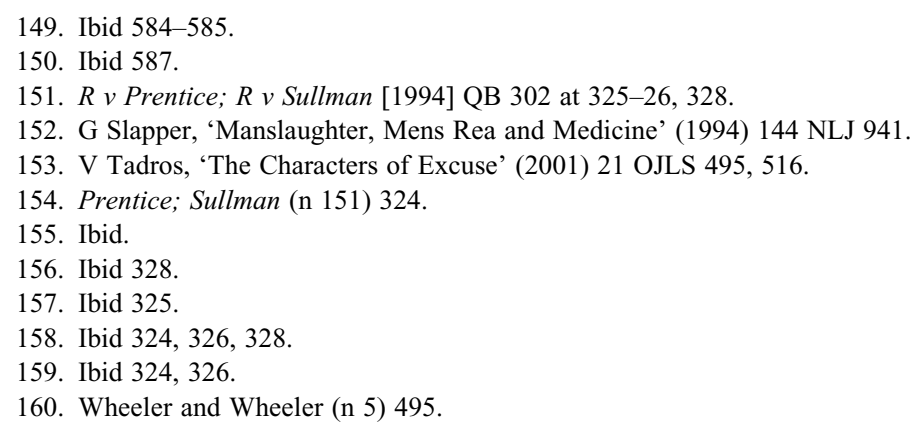


Leaving aside cases where a clinician intentionally harms their patient, it is submitted that no clearer indication of a doctor's failure to properly carry out their mandated duty can be demonstrated than by conduct which amounts to a betrayal of trust. The Law Commission has previously noted how despite the lack of subjective fault, punishment for death resulting from gross negligence is hardly unprincipled, ${ }^{161}$ as in most instances, the defendant has willingly agreed to perform a particular role for personal gain. ${ }^{162}$ As a 'special functionary', it is therefore not possible to forgive their failure to recognise the consequences of their behaviour. ${ }^{163}$ Even though the altruistic nature of healthcare professional should not be overlooked, replacing the test for gross negligence with one based on a betrayal of trust may therefore be defended as ensuring that only healthcare professionals who truly warrant punishment are subject to penal sanctions. However, as will be subsequently argued, in exculpating the conduct of those such as Honey Rose, yet extending punishment to the truly inadvertent defendants who do not demonstrate indifference to the welfare of their patients, such as Dr Adomako, this argument does not hold true.

Wheeler and Wheeler claim that in contrast to the illusive circularity of gross negligence, a betrayal of trust also benefits from 'intuitive' simplicity and ease of application. ${ }^{164}$ As previously noted, the precise point at which negligence becomes criminal has historically been problematic. ${ }^{165}$ By way of contrast, Wheeler and Wheeler believe that both 'betrayal' and 'trust' are 'plain everyday English words', being frequently employed in a variety of everyday settings. Conduct amounting to a betrayal of trust results in a 'gut feeling' that the defendant warrants punishment, so the test proposed by the authors does not require any detailed legal explanation. ${ }^{166}$ Given the significant role that the public play in our criminal justice system, it is imperative that the criminal law is free of unnecessary technicalities and words which amount to no more than a legal fiction. ${ }^{167}$ The criminal law 'expresses the morality of the simple man', and to ensure that the public understand why an individual has been found guilty, the law ought to be articulated in plain terms. ${ }^{168}$ Accordingly, adopting the language of betrayal of trust could potentially introduce greater clarity into the law.

Replacing gross negligence with a 'visceral' test may be considered a solution which is far more than a semantic change. The confusion created by gross negligence is such that in seeking to determine when to pursue charges against the errant physician, prosecutors rely on 'gut instinct', ${ }^{169}$ as do members of the jury. ${ }^{170} \mathrm{~A}$ shift within the substantive law to a betrayal of trust test would therefore harmonise the standards employed by both prosecutors and jurors with the ingredients of the offence. ${ }^{171}$ Within a medical context, gross negligence is hardly a matter of 'science', but rather one of 'gut feeling and ... fairness', ${ }^{172}$ and given that its true meaning is hidden to all, continued reliance on the term is questionable. ${ }^{173}$ Removing uncertainty by aligning the law with a test based on a betrayal of trust may therefore be an eminently logical suggestion.

In addressing the role of experts, by adopting a betrayal of trust test, the role of the expert at trial would be reduced. ${ }^{174}$ As opposed to efforts to fix the conduct of the defendant 'on a sliding scale for

161. Law Commission (n 23) [5.36].

162. Ibid [5.37].

163. Ibid.

164. Wheeler and Wheeler (n 5) 494.

165. P Dean, 'Manslaughter and Dangerous Driving' (1937) 53 LQR 380, 383.

166. Wheeler and Wheeler (n 5) 494.

167. SH Pillsbury, Judging Evil: Rethinking the Law of Murder and Manslaughter (New York University Press, New York 1998) 73.

168. GH Gordon, 'Subjective and Objective Mens Rea' (1975) 17 CLQ 355, 375.

169. Quick, 'Medicine, Mistakes and Manslaughter' (n 1) 193.

170. Wheeler and Wheeler (n 5) 494.

171. Ibid.

172. O Quick, 'Medical Manslaughter-Time for a Rethink?' (2017) 85 Med Leg J 173, 178.

173. Quick, 'Medicine, Mistakes and Manslaughter' (n 1) 193.

174. Wheeler and Wheeler (n 5) 494. 
which they have no personal point of reference', ${ }^{175}$ under the authors' test, the jury would only need to answer a simple question: Did the doctor 'betray the trust [of their patient?]' ${ }^{176}$ It is arguable that the clarity within the authors' proposals could also extend to the pre-trial stage. More specifically, since any expert would not be required to grapple with gross negligence, but rather apply their 'intuitive test', ${ }^{177}$ the prospect of fictional definitions being employed to evaluate the conduct of the doctor would be removed.

Applying the betrayal of trust test to more contemporary case law than examined by Wheeler and Wheeler produces some defensible outcomes. For example, notwithstanding the presence of "classic and persistent signs of infection', ${ }^{178}$ in failing to identify and treat the post-operative complications of the deceased, the conduct of the two senior house officers in Misra and Srivastava ${ }^{179}$ may be regarded as being worthy of criminal punishment. ${ }^{180}$ Their clinical failures evinced behaviour indicative of subjective fault, ${ }^{181}$ with their conduct displaying a disregard for the victim's health. ${ }^{182}$ Despite their assertations that they had 'done [their] best' and '[acted] in good faith', ${ }^{183}$ when viewed against the backdrop of sustained and blatant symptoms of infection, and their failure to appropriately respond to these, it is inconceivable that the welfare of their patient was their primary concern. ${ }^{184}$ The catalogue of errors within their conduct, namely the failure to take blood cultures, ${ }^{185}$ and the indifference to the blood tests undertaken by their colleagues, ${ }^{186}$ all produce the 'visceral gut feeling ${ }^{187}$ that both house officers betrayed their patient's trust. The level of care delivered 'did not even begin to approach the standard ... expected of them', ${ }^{188}$ with the result that it is difficult to reach a conclusion that they ever acted in the best interests of their patient. Accordingly, under both gross negligence and an approach based on a betrayal of trust, both house officers would rightly be held criminally responsible.

The benefits of a binary test are equally apparent when the conduct of Dr Kovvali ${ }^{189}$ is examined. An out of hours locum doctor, Dr Kovvali was sent to examine Andrew Fellows, following a call made by his mother to Prime Care. ${ }^{190}$ Notwithstanding the presence of 'classic signs of diabetic ketoacidosis', 191 Dr Kovvali presented himself with no medical equipment, failed to undertake a physical examination of the patient, or perform a blood sugar test, and falsified his attendance log. ${ }^{192}$ Given the nature of his clinical failures, the conduct of Dr Kovvali is clearly grossly negligent, and also a breach of his fiduciary duty amounting to a betrayal of trust. An agent whose actions are the product of a 'fault of character' can be considered the proper subject of 'moral blame', ${ }^{193}$ and when viewed as a whole, the clinical failures of Dr Kovvali may be characterised as being the product of gross indifference to the welfare of his

175. Ibid.
176. Ibid.
177. Ibid.
178. Misra and Srivastava (n 12) [4].
179. Misra and Srivastava (n 12).
180. Crosby (n 80) 242-43.
181. Griffiths and Sanders (n 1) 125.
182. Tadros (n 103) 85.
183. Misra and Srivastava (n 12) [23].
184. Tadros (n 103) 85.
185. Misra and Srivastava (n 12) [9].
186. Ibid [11].
187. Wheeler and Wheeler (n 5) 494.
188. Misra and Srivastava (n 12) [18].
189. Kovvali (n 12).
190. Ibid [2]-[4].
191. Ibid [8].
192. Ibid [4], [20].
193. RB Brandt, 'Blameworthiness and Obligation' in AI Melden (ed), Essays in Moral Philosophy (University of Washington
$\quad$ Press, Seattle 1958) 12. 
patient. In providing evidence of a reprehensible character, it is only fitting that a betrayal of trust test inculpates such conduct.

On the other hand, the exculpatory properties of the authors' test are apparent when the conduct of Dr Rudling ${ }^{194}$ is scrutinised. When faced with the symptoms displayed by the patient, 'no guidelines' existed as to the most appropriate course of conduct for a GP to take. ${ }^{195}$ Accordingly, other GP's may have also chosen not to arrange a home visit, with the result that the patient's condition would have remained hidden. ${ }^{196}$ The limits of any GP to carry out face-to-face assessments must be acknowledged, ${ }^{197}$ and even the most vehement critic of the medical profession would surely agree that Dr Rudling's failure to personally examine a patient with symptoms which 'might concern a GP'198 is from an academic perspective, far from a breach of her fiduciary duty in a way that amounts to a betrayal of trust.

As a proposal to remedy the inconsistencies present within the offence of gross negligence manslaughter, in light of the cases examined, the test advocated by Wheeler and Wheeler may therefore be considered a sound solution, which not only introduces much needed clarity, but sets the threshold of criminal responsibility at an appropriate level. However, notwithstanding the cogency of their arguments, a number of doubts may be cast on the efficacy of their claims. The ensuing discussion of the betrayal of trust test will highlight how the reconceptualised offence cannot be adopted in its current form as a solution to the issues raised by prosecutions for medical manslaughter.

\section{Betrayal of Trust-An Unworkable solution?}

When subject to closer examination, doubts may be cast on both the ingredients of the novel offence, and its application to the existing case law. Adopting the concept of betrayal of trust as the threshold of culpability, Wheeler and Wheeler note that this is similar to a breach of a fiduciary duty. ${ }^{199}$ The 'unique' nature of the doctor/patient relationship satisfies the ingredients of 'loyalty and responsibility ${ }^{200}$ that are central to the fiduciary role, with this requirement then employed as the initial element of the reconceptualised test. However, despite their reasoning, it is questionable whether the concept of a fiduciary duty is preferable to the existing concept of a duty of care. While it is true that reliance on the 'ordinary principles' of negligence within the current law has caused problems, ${ }^{201}$ as noted above, such issues are of little concern when assessing the criminality of any doctor's conduct. As with the concept of a 'duty of care', the notion of a fiduciary duty is equally a creature of civil law, therefore the well-worn criticisms that apply to Adomako ${ }^{202}$ regarding the use of the civil law to shape the limits of a criminal offence would surely still remain. More importantly, while the notion of a 'duty of care' is arguably well known among the public, the same cannot be said in relation to the concept of a fiduciary duty. The authors acknowledge the difficulties of definition that have troubled the courts when seeking to elucidate the true nature of a 'fiduciary relationship', ${ }^{203}$ and in light of these struggles, it is arguable that explaining the concept to a jury would surely be problematic.

Equally, notwithstanding that the proposed offence omits references to a duty of care, given their penchant for the Bolam test, ${ }^{204}$ it is possible that under the reconceptualised test, experts will continue to

194. Rudling (n 12).

195. Rudling (n 12) [27].

196. Ormerod and Laird (n 25) 592.

197. Rose (n 9) [39].

198. Rudling (n 12) [36].

199. Wheeler and Wheeler (n 5) 493.

200. Ibid 501 .

201. Virgo (n 11); Phillips (n 11); Oliphant (n 11); Reed (n 11); Herring and Palser (n 11).

202. Adomako (n 10).

203. Wheeler and Wheeler (n 5) 493.

204. Quick (n 40) 109. 
use the language of negligence, or more specifically, the standard of the reasonably prudent doctor. As a result, jurors may be left asking when clinical conduct that falls below that of the reasonably prudent clinician amounts to a breach of the doctor's fiduciary duty. As the nature of the breach of duty is the critical issue in cases of medical manslaughter, a preferable alternative would surely be to employ the notion of a betrayal of trust alongside the well-established concept of a duty of care. The jury could then be directed to consider whether the doctor breached their duty of care in a manner that amounts to a betrayal of trust. The requirement of a betrayal of trust could therefore operate as a clearer explanation of conduct that demonstrates 'such disregard for the life and safety of others as to amount to a crime'. ${ }^{205}$ This would encapsulate only the most reprehensible acts as enshrined in Bateman. ${ }^{206}$ Importantly, removing the reference to a fiduciary duty would prevent technical concepts better reserved for the law of trusts from inhibiting the potential clarity that the test proposed by the authors seeks to introduce.

However, where a doctor has committed a clinical error sufficient to attract civil liability, it is not their 'loyalty' to the patient that is being subject to scrutiny. ${ }^{207}$ Rather, the issue is whether they 'fail[ed] to exercise reasonable care and skill, ${ }^{208}$ As the values protected by the fiduciary relationship are not engaged by the doctor's conduct, the concept of a fiduciary duty is inappropriate. ${ }^{209}$ Since claims which are centred on the 'failure [of the doctor] to exercise reasonable care and skill when diagnosing or treating a patient' ought to remain the preserve of tort law, ${ }^{210}$ it is debatable as to why the concept ought to be used to determine the limits of criminal liability for fatal clinical errors.

Any additional clarity brought to the law by the concept of a betrayal of trust test is also reliant upon the terms 'betrayal' and 'trust' being easily understood, which when subject to further scrutiny, may be doubted. Although both are 'everyday English words', ${ }^{211}$ the notion that in themselves, ordinary words will be well understood and familiar to jurors is something of a misconception. ${ }^{212}$ The Criminal Law Revision Committee famously considered the notion of 'dishonest appropriation' to be one which would be 'easily understood', ${ }^{213}$ yet dispute for nearly half a century at the highest judicial level relating to the true meaning of the terms 'appropriation, 214 and 'dishonesty' 215 indicates otherwise. Similarly, the terms 'intention, ${ }^{216}$ and 'recklessnesss ${ }^{217}$ are 'ordinary words of the English language', ${ }^{218}$ yet their true meaning has been the subject of prolonged debate. ${ }^{219}$ In addition to a breach of loyalty, the dictionary interpretation of 'betrayal' is to 'act treacherously..., , ${ }^{220}$ while common synonyms for the term,

205. Bateman (n 12) 12, per Lord Hewart CJ.

206. Ibid.

207. A Grubb, 'The Doctor as Fiduciary' (1994) 47 CLP 311, 323.

208. Ibid.

209. Ibid.

210. Ibid.

211. Wheeler and Wheeler (n 5) 494.

212. Large v Mainprize [1989] Crim LR 213, 213-14.

213. Criminal Law Revision Committee, Eighth Report: Theft and Related Offences, Cmd 2977 (1966) [34]-[39].

214. Lawrence v Metropolitan Police Commissioner [1972] AC 626; $R$ v Morris [1984] AC 230; DPP v Gomez [1993] AC 442; $R v$ Hinks [2001] 2 AC 241.

215. $R$ v Feely [1973] QB 530; $R$ v Ghosh [1982] QB 1053; Ivey v Genting Casinos UK Ltd (t/a Crockfords Club) [2017] UKSC 67; $R$ v Booth [2020] EWCA Crim 575.

216. Hyam v DPP [1975] AC 55; $R$ v Moloney [1985] AC 905; $R$ v Hancock; $R v$ Shankland [1986] AC 455; $R v$ Nedrick [1986] 1 WLR 1025; $R v$ Woollin [1999] 1 AC 82; $R v$ Matthews; $R v$ Alleyne [2003] EWCA Crim 192.

217. $R v$ Cunningham [1957] 2 QB 396; $R v$ Caldwell [1982] AC 341; $R v$ Lawrence [1982] AC 510; $R v$ G; $R$ [2003] UKHL 50, [2004] 1 AC 1034; Attorney General's Reference (No 3 of 2003) [2004] EWCA Crim 868.

218. D Ormerod and K Laird, Smith and Hogan's Text, Cases, and Materials on Criminal Law (13th edn OUP, Oxford 2020$) 96$.

219. G Williams, 'Recklessness Redefined' (1981) 40 CLJ 252; J McEwan and J Robillard, 'Recklessness: The House of Lords and the Criminal Law' (1981) 1 LS 267; G Williams, 'Intention and Recklessness Again' (1982) 2 LS 189; G Williams, 'The Unresolved Problem of Recklessness' (1988) 8 LS 74; AP Simester, 'Murder, Mens Rea, and the House of Lords-Again' (1999) 115 LQR 17; Cath Crosby, 'Recklessness-The Continuing Search for a Definition' (2008) 72 JCL 31.

220. Oxford University Press, Oxford English Dictionary (7th edn OUP, Oxford 2012) 61. 
namely 'double cross', '[backstabber]' and 'sell out', ${ }^{221}$ all indicate some degree of subjective fault, possibly even an intention to cause harm. Given the lack of definition within the test, jurors may interpret a betrayal of trust as requiring a higher form of subjective fault than required under Rose, ${ }^{22}$ and be reluctant to convict absent evidence that the defendant doctor intended to harm their patient. Alternatively, they may think that any mistake by a doctor amounts to a betrayal of trust, and convict for minor mishaps which gross negligence manslaughter would currently not encompass. Although the authors consider that the terms 'betrayal' and 'trust' 'do not require technical explanation', ${ }^{223}$ reliance on 'plain English words', with no further judicial clarification does little to promote uniform application of the law. $^{224}$ The lack of clarity provided by the test for gross negligence has long been criticised as being vulnerable to 'inconsistent verdicts', ${ }^{225}$ with the law failing to safeguard against juror bias. ${ }^{226}$ While Wheeler and Wheeler do refer to the 'duty to act with loyalty and good faith' as being 'at the heart of [their] test', ${ }^{227}$ effectively offering further guidance on what amounts to a betrayal of trust, absent express inclusion in the ingredients of their offence, there is no guarantee that jurors will rely on these terms when assessing the criminality of any doctor's conduct. Without a codified interpretation of what amounts to a betrayal of trust, the test as advanced by the authors has the potential to preserve the worrying levels of inconsistency and unfairness that plagues gross negligence.

In support of their reconceptualised offence, Wheeler and Wheeler cite prosecutions brought under s 4 Fraud Act 2006, noting that at present, jurors are familiar with determining the guilt of a defendant based on 'breaches of position of trust'. ${ }^{228}$ Given that the threshold for a 'breach of trust' is lower than a 'betrayal', the authors note that juries would not face any real difficulties distinguishing whether the conduct of any clinician amounted to a betrayal of trust. ${ }^{229}$ This is in marked contrast to gross negligence, where the jury lack any true measure of when conduct is either criminal or civil.

However, while jurors may face little difficulty determining the guilt of a defendant for the purposes of an offence contrary to s 4 , it is submitted that within the context of culpable clinical harm, the inherently complex nature of medicine is such that parallels with fraud by abuse of position are hardly illustrative. Irrespective of the actual position held by the defendant, 'safeguard[ing] or not act[ing] against, the financial interests of another person, ${ }^{230}$ are duties that require little explanation. When assessing whether the defendant charged with an offence contrary the 2006 Act has committed a breach of trust, jurors therefore need little assistance in identifying the type of conduct that is at odds with the role that they occupy. The concepts of 'gain' and 'loss' ${ }^{231}$ through illicit means are well understood, while the requirements that the defendant act 'dishonestly' and with an intention to 'make a gain for [themselves] or another', ${ }^{232}$ or 'to cause loss to another or to expose another to a risk of loss', ${ }^{233}$ serve to focus the mind of the jury on whether the conduct of the defendant amounted to a 'breach of trust'. As a result, jurors can use their life experience to determine whether the conduct of the defendant satisfies the elements of the offence.

221. Oxford University Press, Concise Oxford Thesaurus (3rd edn OUP, Oxford 2007) 74.

222. Rose (n 9).

223. Wheeler and Wheeler (n 5) 494.

224. Criminal Law Revision Committee, Fourteenth Report: Offences against the Person, Cm 7844 (1980) [7].

225. CMV Clarkson, 'Context and Culpability in Involuntary Manslaughter: Principle or Instinct?' in A Ashworth and B Mitchell (eds), Rethinking English Homicide Law (OUP, Oxford 2000) 137.

226. N Hodson, 'Permission without Direction: Gross Negligence Manslaughter and Erasure following Bawa-Garba' (2019) 26 EJHL $183,188$.

227. Wheeler and Wheeler (n 5) 495.

228. Fraud Act 2006, s 4.

229. Wheeler and Wheeler (n 5) 498.

230. Fraud Act 2006, s 4(1)(a).

231. Ibid, s 4(1)(c)(i)-(ii).

232. Ibid, s 4(1)(c)(i).

233. Ibid, s 4(1)(c)(ii). 
By way of contrast, beyond superficial statements, without expert evidence, it is unlikely that most jurors would be able to explain the clinical responsibilities of the practitioner in the dock. Having regard to the distressing facts of medical manslaughter cases, and their unfamiliarity with medical matters, jurors may be unable to divorce the outcome of death from the question of whether the conduct of the defendant doctor amounts to a betrayal of trust. While it is true that jurors would be able to identify medical errors which are truly beyond the pale as amounting to a betrayal of trust, the same can be said of the test of gross negligence. More specifically, where the conduct is so inherently bad, a juror's absence of medical knowledge, and the potentially vague nature of gross negligence is hardly fatal, as the actions of the defendant doctor are so clearly beyond that of the reasonable practitioner to be criminal.

Even if jurors lack understanding of civil negligence, the concept nevertheless reinforces the salient point that not all fatal medical errors warrant criminal punishment. This has long been recognised as a redeeming factor within Bateman, ${ }^{234}$ with the emphasis on the need for the negligence of the defendant to go 'beyond a mere matter of compensation between subjects', ${ }^{235}$ clearly highlighting that criminal sanctions should not be pursued lightly. ${ }^{236}$ When assessing the grossness of a doctor's conduct, the jury are therefore alert to the possibility that while blameworthy, the defendant doctor may not warrant criminal punishment. Absent any lesser fault standard to ground their assessment of a doctor's conduct, rather than evaluate the culpability inherent within the errant clinician's behaviour, jurors may simply conclude that in failing to preserve life where others would have, the doctor must have betrayed the trust of their patient, and therefore deserve punishment. A betrayal of trust test may consequently result in jurors adopting a particularly punitive view of any clinician in the dock.

Further, the claim that the intuitive nature a betrayal of trust test would reduce the possibility for the role of the jury to be usurped by the expert is also dubious. ${ }^{237}$ Although experts may play a reduced role, as previously highlighted, under the proposals of Wheeler and Wheeler, jurors will still lack medical knowledge. Consequently, leaving aside truly abysmal clinical care, expert evidence would still be necessary, if not vital in difficult cases. A brief study of the reported cases reveals the condemnatory language employed by experts during the trial process, with the conduct of Dr Adomako lambasted as a 'gross dereliction of care', ${ }^{238}$ and the optical failures of Honey Rose considered to be at the 'rock bottom' of care expected by any competent optometrist. ${ }^{239}$ Given the 'visceral' nature of a betrayal of trust, ${ }^{240}$ it is not difficult to envisage emotive terms being seized upon by the jury as indicative of the defendant's guilt. Moreover, if jurors currently rely on gut instinct due to the lack of clarity provided by gross negligence, ${ }^{241}$ and are still subject to persuasion by the expert, adopting a test based on 'gut instinct' here would hardly obviate the potential for jury usurpation. Rather, if their instincts are already being overridden by the evidence of experts, any shift to the test proposed by the authors would merely be a linguistic change that is still prone to such issues.

In support of their offence, Wheeler and Wheeler assert that due to the 'intuitive' nature of a betrayal of trust, the 'clarity' brought to the law would make it 'easier to pass the notional legal advice test'. 242 Accordingly, previously highlighted criticisms directed at the compliance of gross negligence manslaughter with Article 7(1) ECHR ${ }^{243}$ could be remedied. However, it is debatable as to whether this holds true. As Fitzpatrick has highlighted, in addition to preventing the defendant from identifying why the

\footnotetext{
234. Bateman (n 12).

235. Ibid 11-12, per Lord Hewart CJ.

236. Simester and others (n 44) 432.

237. Wheeler and Wheeler (n 5) 494.

238. Adomako (n 10) 182.

239. Rose (n 9) [28].

240. Wheeler and Wheeler (n 5) 494.

241. Ibid.

242. Ibid 498

243. ECHR (n 50).
} 
jury regarded their behaviour as sufficiently gross as to be criminal, the offence of gross negligence equally fails to provide any clarification on the 'standard of grossness applied by the jury'. ${ }^{244}$ This same criticism may be directed at the betrayal of trust test. When seeking guidance on when any breach of a fiduciary duty will become criminal, the defendant doctor is simply met with the answer, "when the breach amounts to a betrayal of trust'. When the question of 'when does a breach of a fiduciary duty amount to a betrayal of trust' is then posed, the answer is simply 'when the jury considers it to be so'. No further information is available, and the defendant is denied any real objective criteria with which to determine when any medical error may attract criminal sanctions. Intuition is hardly a measurable concept, and what may be intuitive to a doctor, or a legal professional well versed in matters of fatal medical negligence may widely differ from that of the average juror. Rather than passing the 'notional legal advice test', the test proposed by the authors simply rephrases the time old question of 'when does negligence become sufficiently gross as to be criminal', to 'when does a breach of a fiduciary duty amount to a betrayal of trust', and 'what amounts to a betrayal of trust to be sufficiently bad as to be criminal'. In both instances, the answer is simply when the jury consider it to be so, with the result that under a betrayal of trust test, any doctor seeking to identify when they may be judged criminal is left fumbling for answers.

The reformulated offence as advocated by the authors may also be criticised for failing to address the previously discussed issues of moral luck. As outlined by Wheeler and Wheeler, only conduct resulting in death would attract criminal punishment. ${ }^{245}$ Where a doctor breaches their fiduciary duty in a manner that amounts to a betrayal of trust, yet the death of the patient is avoided, criminal sanctions would not follow. In restricting their reconceptualised offence to fatal errors, the lack of any lesser offence for the practitioner who causes serious harm due to their betrayal of trust would therefore preserve the current position, with luck determining whether any errant clinician faces criminal prosecution for manslaughter. Although civil and regulatory sanctions are available, ${ }^{246}$ if the concept of a betrayal of trust is so egregious that it warrants elevation to a threshold of criminality, it is questionable why a betrayal of trust resulting in serious harm should escape criminal punishment. Rather, it may be asserted that a betrayal of trust causing serious harm should also attract criminal sanctions in the form of a lesser included offence.

This criticism is mitigated by the alternative criminal sanctions that may follow where conduct sufficient to satisfy the betrayal of trust threshold only results in harm, as opposed to the death of the patient. A doctor who has subjective foresight of a serious and obvious risk of death, yet nevertheless takes that risk, resulting in serious harm to their patient, would surely be regarded as having breached their fiduciary duty in a manner that amounts to a betrayal of trust. As noted above, the offence of wilful neglect necessitates subjective fault, ${ }^{247}$ and 'controversially', is not contingent on harm to the patient materialising. ${ }^{248}$ Accordingly, as with reckless conduct that currently meets the threshold for gross negligence yet does not result in death, non-fatal betrayals of trust where the clinician is aware of the risks associated with their conduct may still face identical criminal sanctions. However, if as discussed above, $\operatorname{Rose}^{249}$ has harmonised the fault threshold for gross negligence with that of wilful neglect, in inculpating grossly negligent conduct amounting to a betrayal of trust, the authors' proposals will result in a return to the inconsistency for the fault levels between manslaughter and wilful neglect, as identified by Kazarian. ${ }^{250}$

244. Fitzpatrick (n 49) 130.

245. Wheeler and Wheeler (n 5) 492.

246. In particular, the GMC Sanctions Guidance notes that erasure from the medical may be considered a necessary sanction where the doctor 'seriously harms others' or 'abuses their position of trust', General Medical Council, GMC Sanctions Guidance (MPTS, 2018) paras 109C-D. Erasure may be the most germane sanction where the doctor's actions demonstrate subjective fault, General Medical Council, GMC Sanctions Guidance (MPTS, 2018) paras 129, 132.

247. Patel (n 134); Turbill (n 135) [13], [17].

248. O Quick, Regulating Patient Safety: The End of Professional Dominance? (CUP, Cambridge 2017$) 117$.

249. Rose (n 9)

250. Kazarian (n 137) 399-400. 
From the perspective of fair labelling, the breadth of medical killings caught by the reconceptualised offence is also objectionable. At first glance, if the authors' proposals are successful in restricting criminal prosecution to those who have betrayed the trust of their patient in a morally blameworthy manner, the proposed reformulation may be praised for raising the threshold of criminality. Exculpating fatal medical errors committed in 'good faith', ${ }^{251}$ the test would surely satisfy calls to ensure that only killings which deserve the stigmatic label of manslaughter result in prosecution. Yet on closer examination, the same flaws which beset the current law are present again in the reformed test. Although a jury may consider the doctor's mental state as being relevant to a betrayal of trust, deeming a doctor's willingness to run an unjustified risk as being contrary to the patient's best interests, and therefore criminal, under the authors' proposals, consideration is not expressly given to the doctor's awareness of the risks associated with their conduct at the time of acting. As a result, it bridges both objective and subjective mens rea, encompassing conduct which at present amounts to gross negligence, and subjective recklessness. This is apparent from the analysis undertaken by the authors, as they note that Dr Adomako would be inculpated by their proposals. ${ }^{252}$

As previously noted, although Adomako failed to identify why his patient had stopped breathing, he nevertheless sought to fulfil his duty by undertaking the clinical steps that he considered were necessary in the circumstances. While mistaken, his efforts cannot surely be considered to be contrary to the interests of his patient, ${ }^{253}$ or indicative of a lack of good faith. Even accepting the claim made by that Wheeler and Wheeler that his conduct is sufficient to amount to a betrayal of trust, ${ }^{254}$ as he was unaware that the endotracheal tube had become dislodged, his absence of choice to run the risk of harm still renders his culpability lower than that of the doctor whose betrayal of trust is attributable to recklessness, such as Doctors Misra and Srivastava. However, both are caught by the broad notion of a betrayal of trust. In failing to distinguish between betrayals where the defendant was alert to the risk within their conduct, from those where they merely ought to have been, the reconceptualised offence can hardly be said to provide a fair representation of the defendant doctor's conduct to society. Gibson and Reed have noted that by encompassing both advertent and inadvertent killings within the offence of gross negligence, the crime fails to properly emphasise the moral culpability of the reckless killer, "positively mispresent[ing] [their] blameworthiness'. ${ }^{255}$ In encompassing deaths attributable to both gross negligence and recklessness, this criticism equally holds true with Wheeler and Wheeler's proposals.

Although the difference in culpability between one who recklessly harms their patient, and one who inadvertently does so may be reflected during the sentencing process, the degree of communication to the public offered by the sentence is hardly as clear as the offence label itself. Furthermore, in contrast to the sentence, the label possesses a greater degree of longevity. ${ }^{256}$ 'Manslaughter' has been described as a 'lurid' term, ${ }^{257}$ and even where their conduct amounts to a betrayal of trust, for the truly inadvertent defendant to be tarred with the same brush as the reckless killer is wholly unacceptable. This is especially so where the death occurred in circumstances where the defendant was engaged in a socially useful role such as healthcare. Although the appropriate label which ought to be attached to any criminal offence is an inherently subjective question, ${ }^{258}$ the breadth of views ought not to be employed to dilute or distract from the true importance of fair labelling. ${ }^{259}$ Society understands that harm which is attributable to reckless or deliberate harm should not be regarded in the same light as that which is the result of

251. Wheeler and Wheeler (n 5) 495.

252. Ibid.

253. Tadros (n 103) 84.

254. Wheeler and Wheeler (n 5) 495.

255. Gibson and Reed (n 87) 42.

256. T Crofts, 'Labelling Homicides' (2009) 17 Ann Rev Law Ethics 355, 366.

257. J Horder, Homicide and the Politics of Law Reform (OUP, Oxford 2012) 151.

258. Law Commission, A New Homicide Act for England And Wales? Cp 177 (2005) [1.46].

259. Crofts (n 256) 365. 
medical error. ${ }^{260}$ Given the socially valuable role played by physicians, any reform of gross negligence manslaughter within a medical setting ought to therefore properly acknowledge the principle of fair labelling. Regrettably, by inculpating Dr Adomako, the test proposed by Wheeler and Wheeler flouts the principle of fair labelling and can hardly be considered to be an improvement on the present law.

The principle cannot, however, be restricted solely to the 'name of the abstract offence'. ${ }^{261}$ Rather, the constituent elements of any crime should enable members of the public to identify the 'moral' wrong inherent within the defendant's conduct. ${ }^{262}$ In order to prevent impeding the communicative role of the criminal law, the label ought to correspond with 'society's understanding of the real meaning of the offence'. ${ }^{263}$ Although not expressly clear, in seemingly retaining the offence label 'gross negligence manslaughter', yet amending the elements of the crime, difficulties arise with Wheeler and Wheeler's proposals. To equate breach of a fiduciary duty with manslaughter is to introduce technical legal concepts into a serious criminal offence, and as a yardstick with which to judge the conduct of those convicted of gross negligence manslaughter, breach of a fiduciary duty does not properly enable the public to identify the moral wrong committed by the defendant. Research suggests that the public use the term 'manslaughter' to encompass mercy killings, killings which are the result of duress, and those where criminal charges would follow due to the commission of an unlawful act resulting in death. ${ }^{264}$ Although it may be asserted that the requirement of a fatal 'breach of trust' is sufficient to encapsulate the moral turpitude of the defendant, to equate a betrayal of trust with manslaughter is arguably one which is far removed from the social usage of the term, thus obscuring the communicative impact of the criminal law.

When the betrayal of trust test is subject to further scrutiny, it is also possible to identify a number of inconsistencies with the operation of the offence. Although not alone in their assessment of Dr Adomako's culpability, ${ }^{265}$ it is submitted that the analysis of his blameworthiness as undertaken by Wheeler and Wheeler fails to properly address the institutional errors present within the case, ${ }^{266}$ and the presence of 'good faith' demonstrated by his response to the patient's struggles. Given the authors' claims that a test based on a 'fiduciary duty' permits a 'more holistic approach' to the determination of any defendant doctors guilt, ${ }^{267}$ the short shift with which they give clear 'excusing and mitigating circumstances ${ }^{268}$ is surprising. In particular, at the time of the incident Dr Adomako was working multiple shifts, with very little sleep. He did not initiate the anaesthetic, and when he took over from his colleague, he was working without the operating department assistant. ${ }^{269}$ Anaesthesia remains a complex art, ${ }^{270}$ and to safeguard the welfare of the patient, the 'continuous presence' of a 'competent dedicated anaesthetic [assistant]' is imperative. ${ }^{271}$ Its absence has indeed been found to play a causal role in the occurrence of patient safety events. ${ }^{272}$ Notwithstanding this requirement, during the critical points of the operation, Dr Adomako was

260. General Medical Council (n 4) 4.

261. Williams (n 100).

262. Zawati (n 106) 27.

263. Ibid 137-38.

264. B Mitchell, 'Public Perceptions of Homicide and Criminal Justice' (1998) 38 Brit J Criminol 453, 466.

265. M Baron, 'The Standard of the Reasonable Person in the Criminal Law' in RA Duff and others (eds), The Structures of the Criminal Law (OUP, Oxford 2011) 26.

266. Lord Williams of Mostyn QC and A Curnow QC, 'Death under Anaesthetic: The Case of Dr Adomako' (1996) 36 Med Sci Law 188, 191; JP Adams, MDD Bell and AR Bodenham, 'Quality and Outcomes in Anaesthesia: Lessons from Litigation' (2012) 109 Br J Anaesth 110, 114.

267. Wheeler and Wheeler, (n 5) 499.

268. M Hor, 'Medical Negligence: The Contours of Criminality and the Role of the Coroner' (1997) 1997 Sing JLS $86,100$.

269. $R$ v Adomako [1994] QB 302 at 330.

270. AF Merry and A McCall Smith, Errors, Medicine and the Law (CUP, Cambridge 2001) 46.

271. Royal College of Anaesthetists, Chapter 3: Guidelines for the Provision of Anaesthesia Services (GPAS): Guidelines for the Provision of Anaesthesia Services for Intraoperative Care 2019 (RCoA, 2019) 5.

272. MT Kluger, M Bukofzer and M Bullock, 'Anaesthetic Assistants: Their Role in the Development and Resolution of Anaesthetic Incidents' (1999) 27 Anaesth Intensive Care 269. 
the sole anaesthetist. ${ }^{273}$ Consequently, in light of the evidence of systematic failures present within the circumstances of the case, to assert that his conduct demonstrated a betrayal of trust that is so severe to be deserving of criminal punishment to therefore adopt a particularly punitive assessment of Adomako's behaviour.

Equally, although flawed, in seeking to diagnose why his patient had stopped breathing, and perform all the steps that he considered necessary, Dr Adomako's behaviour demonstrates that he was 'properly motivated by the patient's interests in survival'. ${ }^{274}$ When subject to scrutiny under the Bateman test, ${ }^{275}$ his conduct hardly demonstrates a 'insufficient regard to the welfare of his patient', and only a 'a severe critic [of his would assert] that he didn't give a damn'. ${ }^{276}$ In seeking to define the limits of criminal responsibility, character theorists have long noted how punishment ought to be reserved for agents whose conduct evinced a blameworthy trait, such as indifference to the welfare to others. ${ }^{277}$ While the conduct of Dr Adomako during the operation provides evidence that his skills as an anaesthetist may be found wanting, given his efforts to assist the patient, to assert that he possessed a blameworthy vice, and merits criminal punishment is unwarranted. ${ }^{278}$ In glossing over both his lack of moral blame and the surrounding institutional failings, Wheeler and Wheeler's assessment of Dr Adomako may therefore be considered to be at odds with their own guidelines as to when fatal clinical conduct will attract criminal punishment.

With regards to external factors, the authors assert that 'inadequate training or an honest mistake... could not be classed as a betrayal of trust'. ${ }^{279}$ Yet inadequate training was a factor in Adomako, ${ }^{280}$ and questions have been asked whether a doctor with questionable 'basic medical knowledge', ${ }^{281}$ who lacked appropriate 'training', ${ }^{282}$ and whose conduct has been described as 'merely incompetent ${ }^{283}$ should attract criminal sanctions? Although the test may fail to properly take into account Adomako's external circumstances, it is successful when applied to Doctors Prentice and Sullman, with the betrayal of trust test seemingly preventing prosecution. ${ }^{284}$ However, it is debatable whether there exists a clear distinction between the gravity of the 'clinical error' committed by Adomako and the mistakes of these two junior doctors. ${ }^{285}$

When applied to Sellu, ${ }^{286}$ the betrayal of trust test is equally found wanting. Although later quashed on appeal, Dr Sellu was initially found criminally responsible for the death of James Hughes, who following a routine knee operation, sustained a perforated bowel, leading to multiple organ failure. ${ }^{287}$ Dr Sellu's conduct contained a number of clinical errors, including the decision not to administer

273. Adomako (n 269).

274. Tadros (n 103) 84.

275. Bateman (n 12) 11-12.

276. P Monks, 'Frankly My Dear, I Don’t Give a Damn’ (1996) 36 Med Sci Law 185, 186.

277. Brandt (n 193) 14; MD Bayles, 'Character, Purpose and Criminal Responsibility' (1982) 1 Law \& Phil 5, 7; N Lacey, State Punishment-Political Principles and Community Values (Routledge, London 1988) 76; P Arenella, 'Character, Choice and Moral Agency: The Relevance of Character to our Moral Culpability Judgments' in E Frankel Paul, FD Miller Jr and J Paul (eds), Crime, Culpability and Remedy (Basil Blackwell, Oxford 1990) 74-75; RA Duff, 'Character, and Criminal Liability' (1993) 12 Law \& Phil 345, 362-63; Tadros (n 103).

278. Tadros (n 25) 51.

279. Wheeler and Wheeler (n 5) 495.

280. Adomako (n 10).

281. D Brahams, 'Two Locum Anaesthetists Convicted of Manslaughter' (1990) 45 Anaesthesia 981.

282. D Brahams, 'Medicine and the Law' (1990) 58 Med Leg J 236, 240.

283. B Lyons, 'The Sleep of Death: Anaesthesia, Mortality and the Courts from Ether to Adomako' in D Griffiths and A Sanders (eds), Bioethics, Medicine and the Criminal Law: Volume 2, Medicine, Crime and Society (CUP, Cambridge 2013$) 61$.

284. Wheeler and Wheeler (n 5) 495.

285. R Palmer, 'Black Sheep, Scapegoats and Lambs to the Slaughter-Some Reflections on the Work of a Protection Organisation' (2000) 68 Med Leg J 130, 136.

286. Sellu (n 12).

287. Ibid [1]-[3], [19]. 
'urgent' medical care, particularly antibiotics, the failure to attend on receiving information detailing the deterioration of the patient and the delay in operating once a perforated colon had been confirmed by the CT scan. ${ }^{288}$

Despite these failings, it may initially be asserted that Sellu's conduct may not demonstrate a betrayal of trust. As opposed to an omission undertaken with knowledge of the consequences, having ordered a 'management plan' and 'urgent CT scan', ${ }^{289}$ the failure to administer antibiotics appears consistent with a significant, yet nevertheless fatal error committed inadvertently. This is not synonymous with a breach of 'loyalty' or 'good faith' that are critical to a betrayal of trust. Likewise, in considering the delay in operating, it is clear that Dr Sellu was alert to the need for surgery, but misjudged the urgency. ${ }^{290}$ This may be attributable to the fact that he was advised that the patient's condition was not 'dangerous' at that time, ${ }^{291}$ with his inability to secure the services of an anaesthetist equally contributing to the reason for the delay. ${ }^{292}$ Consequently, it is plausible that a jury may find that his conduct does not amount to a betrayal of trust. This is especially true when mitigating factors such as the absence of an anaesthetist, and Dr Sellu's apparent lack of knowledge regarding the 'hospital's break in policy', ${ }^{293}$ designed to give priority to patients in urgent need of surgery, are taken in account under the 'holistic approach'294 advocated by the authors.

However, the 'hospital break-in policy' was not local to Clementine Churchill Hospital, but in place throughout the UK, and seemingly common knowledge among all consultants. ${ }^{295}$ Having regard to the contradictory evidence given by Dr Sellu regarding the administration of oral antibiotics, ${ }^{296}$ and the 'inconsistencies' in the evidence he provided to the various investigatory bodies, ${ }^{297}$ a jury might view him as dishonest, and acting contrary to the requirement of 'good faith' and 'loyalty'. Closer examination of his failure to administer antibiotics following the initial examination, and omitting to investigate whether medication had been prescribed prior to surgery, ${ }^{298}$ may also result in a more punitive assessment of his conduct, as it may be argued that it evinces a lack of concern for his patient's welfare. Duff has previously asserted that it is possible to ascertain what any agent cares for by considering what they notice or direct their mind to. ${ }^{299}$ Accordingly, the bride groom who fails to remember their wedding properly warrants criticism, as their failure to remember the occasion evinces a 'lack of concern'. If the 'bride groom' possessed sufficient 'concern [they] could not have forgotten their wedding'. ${ }^{300}$ As noted at Sellu's trial, the administration of antibiotics was an elementary step to take in treating Mr Hughes, ${ }^{301}$ and one which was 'obvious'. ${ }^{302}$ Under Duff's analysis, any reasonably prudent colorectal surgeon who evinced sufficient care for the welfare of their patient would therefore not fail to administer antibiotics to an individual with such symptoms.

Equally, although Dr Sellu sought to have a CT scan performed, given the possibility of free gas in the abdomen, any reasonable colorectal surgeon would have not only sought clarification on the X-rays from

\author{
288. Ibid [22]. \\ 289. Ibid [11]. \\ 290. Ibid [60]-[61]. \\ 291. Ibid [36]. \\ 292. Ibid [61], [66]. \\ 293. Ibid [61], [62]. \\ 294. Wheeler and Wheeler (n 5) 499. \\ 295. Sellu (n 12) [33]. \\ 296. Ibid [12]. \\ 297. Ibid [21]. \\ 298. Ibid [65]. \\ 299. RA Duff, Intention, Agency and Criminal Liability: Philosophy of Action and the Criminal Law (Basil Blackwell, Oxford \\ 1990) 163. \\ 300. Ibid. \\ 301. Sellu (n 12) [8], [39], [47]. \\ 302. $R v$ Sellu (8 November 2013), Sentencing remarks of Mr Justice Nicol <https://www.judiciary.uk/wp-content/uploads/JCO/ \\ Documents/Judgments/r-v-sellu-sentencing-remarks.pdf $>$ accessed 3 August 2020.
}


a radiologist, but requested a scan be performed 'within four or five hours' ${ }^{303}$ Despite the presence of a radiologist when the X-ray was performed, Dr Sellu failed to seek further clarification on the results. ${ }^{304}$ Once again, when examined under the guise of a betrayal of trust, it may be argued that it is difficult to reconcile such conduct with acting in a manner that is in the best interests of Mr Hughes. When the failure to attend is reviewed, given that Dr Sellu had previously examined the patient, ${ }^{305}$ the decision to not attend was also surely one undertaken after considering the potential risks associated with nonattendance. Although it must be acknowledged that Sellu's treatment of Mr Hughes was later found to be consistent with acceptable medical practice, with the result that he was acquitted of any clinical misconduct, ${ }^{306}$ it is relevant that at first instance, a jury, albeit one improperly directed, ${ }^{307}$ still considered his behaviour to be criminal. ${ }^{308}$ When the clinical failures committed by Dr Sellu are viewed cumulatively, given the presence of subjective fault, and the ease at which a number of the omissions could have been remedied, it is therefore more probable that a jury would conclude that the conduct of Dr Sellu is consistent with a breach of a fiduciary duty amounting to a betrayal of trust that warrants punishment.

Although it may be that it is the criminal justice system itself that is not conducive to examining the clinical failures of any physician, ${ }^{309}$ it is arguable that seeking to examine complex medical errors within the confines of the betrayal of trust test fails to take into account the nuances critical to a full assessment of any doctor's culpability. The focus of the jury ought to be on why the defendant did not fulfil his clinical duties. Although it may be asserted that the 'holistic approach' to a betrayal of trust advocated by the authors does in fact permit such questions to be answered, absent express reference within the test for criminal responsibility, it is likely that they will be given insufficient weight. This can be evidenced by the significance that is now attached to Lord Mackay's reference to 'all the circumstances'. ${ }^{310}$ The initial prosecution of Dr Sellu attracted considerable criticism, ${ }^{311}$ notwithstanding the multiple errors initially relied upon by the prosecution, in stark contrast to that of Dr Adomako, who effectively only made one mistake. Despite this, Wheeler and Wheeler's reconceptualised offence could potentially inculpate Sellu, which is surely problematic when viewed alongside claims that the test 'may [produce] fewer prosecutions'. 312

When applied to Rose ${ }^{313}$ it is submitted that the test nevertheless continues to exculpate conduct that ought to be met with criminal punishment. On a cursory examination of the case facts, it may be argued that given the age and the allegedly 'uncooperative' nature of Vincent Barker, ${ }^{314}$ her failure to properly carry out the examination of the back of the eye with the ophthalmoscope does not give rise to a betrayal of trust. Similarly, although it is the role of a competent optometrist to ensure that they examine the correct retinal images for their patient, ${ }^{315}$ in accordance with the 'holistic approach' advocated by Wheeler and Wheeler, consideration must be given to 'all matters' which are pertinent to determining if the conduct of the defendant amounts to a betrayal of trust. ${ }^{316}$ Having regard to the issues accessing the

303. Sellu (n 12) [40].

304. Sentencing remarks of Mr Justice Nicol (n 302).

305. Sellu (n 12) [10].

306. Clare Dyer, 'Sellu is cleared of Medical Misconduct' (2018) 360 BMJ k1089.

307. Sellu (n 12) [156].

308. Ibid [1].

309. Merry and Brookbanks (n 123) 342.

310. Adomako (n 10) 187

311. P McDonald, 'Medical Manslaughter and the case of David Sellu' (2017) 99 RCS Bull 104.

312. Wheeler and Wheeler (n 5).

313. Rose (n 9).

314. Ibid [19].

315. Ibid [12].

316. Wheeler and Wheeler (n 5) 499. 
scans on the computer system, ${ }^{317}$ an especially lenient jury may consider that her clinical failures are merely symptomatic of the fatal consequences which can arise through institutional errors. It is acknowledged that technological issues can have a detrimental impact on an individual's perception and decision-making, which in turn, can contribute to the occurrence of error. ${ }^{318}$ In failing to properly carry out the eye examination of Vincent Barker, it may therefore be asserted that Rose did not betray his trust.

However, it may be argued that given the magnitude of her clinical failings, she demonstrated indifference to the welfare of her patient, betraying his trust. In addressing Horder's claim that both 'indifference' and 'a great departure from an acceptable standard of conduct' amount to gross negligence, ${ }^{319}$ Clarkson has highlighted how an agent's significant failures may be considered indicative of indifference. ${ }^{320}$ In respect of healthcare professionals, Clarkson notes that notwithstanding their expertise, minor deviations attributable to 'tiredness and inattentiveness' are not customarily considered to be symptomatic of indifference warranting penal sanctions. However, where the conduct of the clinician fell so far below that of the reasonably prudent professional, it is possible to 'infer indifference'. Such inferences can be made even where wider systematic failures are present. ${ }^{321}$

With regards to Rose, her failure to properly examine the internal eye structure was a 'fairly massive breach of her duty of care'. ${ }^{322}$ While in itself not disclosing a serious and obvious risk of death, any competent optician would have understood that in failing to undertake a proper eye examination, a potentially fatal condition would remain undetected. ${ }^{323}$ Although this alone is insufficient to give rise to criminal liability, ${ }^{324}$ where it is not possible for an examination with an ophthalmoscope to be undertaken, the omission ought to be noted, with the 'patient re-called within six months' ${ }^{325}$ Yet a subsequent re-test was not scheduled, with Rose also failing to accurately record the service she provided. ${ }^{326}$ In failing to arrange a re-test, with the knowledge possessed by Rose that a potentially fatal condition could be present, although rare, it is questionable why this precaution was not taken. Perhaps the fact that her patient was a young boy meant that she was prepared to run the risks associated with not arranging a re-test as she was obliged to do. Given how far below that of the reasonably prudent optometrist her conduct fell, ${ }^{327}$ it may be alleged that Rose was indifferent to the welfare of Vincent Barker. Consequently, in acting contrary to his best interests, and in a manner that is inconsistent with the obligation of 'loyalty and good faith', Rose's behaviour may be regarded as a betrayal of trust, with the result that she warrants criminal punishment.

Leaving aside the difficulties that arise when seeking to determine whether the conduct of any defendant doctor amounts to a betrayal of trust, it is possible to identify further anomalies with the reconceptualised offence. In particular, although replacing the requirement of gross negligence with a breach of a fiduciary duty amounting to a betrayal of trust is in itself a novel approach, the offence still retains the requirement that the breach 'gives rise to a reasonably foreseeable serious and obvious risk of death' ${ }^{328}$ The authors acknowledge that their proposals 'share similarities ${ }^{329}$ with the ingredients of gross negligence as clarified by Rose, ${ }^{330}$ so the test seemingly remains 'objective and prospective'. Yet

317. Rose (n 9) [19], [25].

318. R Gordon, R Flin and K Mearns, 'Designing and Evaluating a Human Factors Investigation Tool (HFIT) For Accident Analysis' (2005) 43 Safety Sci 147.

319. J Horder, 'Gross Negligence and Criminal Culpability' (1997) 47 UTLJ 495, 496.

320. Clarkson (n 225) 154-55.

321. Ibid 155 .

322. Rose (n 9) [28].

323. Ibid [92].

324. Ibid [86].

325. Ibid [30].

326. Ibid [6], [27], [29].

327. Ibid [28].

328. Wheeler and Wheeler (n 5) 492.

329. Ibid.

330. Rose (n 9). 
in doing so, the requirement of a breach of a fiduciary duty amounting to a betrayal of trust simply becomes another epithet for gross negligence. Accordingly, the reasonably competent optometrist who equally committed a betrayal of trust would still not possess knowledge that the failure to undertake the eye examination would give rise to a serious and obvious risk of death. At the very most, all that would be present is the risk that a serious condition could go undiagnosed, which as confirmed by the Court of Appeal, is in no way synonymous with knowledge of a 'serious and obvious risk of death' ${ }^{331}$ While it may be argued that due to the potentially egregious nature of conduct amounting to a betrayal of trust, a serious and obvious risk of death will customarily be present, under Wheeler and Wheeler's proposals, it is still the foreseeability requirement that continues to exclude Rose from criminal liability. Having regard to her clear moral culpability, when contrasted with authors' assessment of Dr Adomako, such a result remains unpalatable.

\section{Conclusion}

It is painfully clear that notwithstanding recent judicial developments, the offence of gross negligence manslaughter remains deeply flawed. Contemporary pronouncements that the conduct of the defendant must be 'truly exceptionally bad' to merit punishment cannot be considered to have added significant clarity to Lord Mackay's circular test in Adomako. ${ }^{332}$ Equally, the 'objective and prospective' test of foreseeability, as confirmed in Rose ${ }^{333}$ effectively exculpates clinical conduct which demonstrates indifference to the victim, and is contrary to Bateman. ${ }^{334}$ The breadth of the offence label fails to communicate the moral culpability of the defendant clinician, and despite the introduction of the crimes of ill treatment and wilful neglect, the absence of any lesser offence of gross negligence resulting in serious harm still renders the crime reliant on moral luck to an offensive degree.

The reconceptualised offence advocated by Wheeler and Wheeler may be praised for encapsulating the principle that any doctor who commits a fatal betrayal of trust which demonstrates a lack of good faith is not fit for the role, and is deserving of criminal punishment. However, in relying on 'plain English words', the test offers little by the way of real clarity with which to determine when clinical errors will cross the boundary between civil and criminal liability. Beyond truly egregious clinical conduct, jurors may not only struggle to identify criminal clinical errors, but possess widely diverging views as to what amounts to the requisite betrayal of trust. The concept of a fiduciary duty may also be problematic. As a result, the proposed offence is likely to perpetuate the inconsistency found within the current law. Grouping both advertent and inadvertent medical killings within one crime, the authors' proposals pay little respect to the principle of fair labelling, thus failing to resolve the issues that are inherent within gross negligence manslaughter. This leaves the clinician whose unintentional betrayal of trust causes the death of their patient still at the mercy of moral luck. Moreover, in maintaining the 'objective and prospective' test of foreseeability, the betrayal of trust test arguably fails to inculpate morally blameworthy defendants, such as Honey Rose, yet equally continues to punish physicians who lack indifference for the welfare of their patient, such as Dr Adomako.

Ultimately, as opposed to offering a mere linguistic alternative to gross negligence, any proposed reform must fully address the shortcomings that plague the current offence. The critical point at which fatal clinical errors warrant punishment must be identified, with the means of capturing this set out in a manner beyond vague and malleable terms such as 'truly exceptionally bad', or 'betrayal of trust'. While the test advocated by Wheeler and Wheeler ought to be applauded for providing an alternative to the well-rehearsed calls for subjective recklessness, in light of the flaws detailed with their proposals, the 
test cannot be adopted in lieu of the current law. Accordingly, it is submitted that in seeking to resolve the issues of medical manslaughter, we must once again go back to the drawing board.

\section{Acknowledgements}

My sincere thanks to Dr Cath Crosby and Dr Anne Lodge, for their invaluable comments on earlier drafts of this article.

\section{Declaration of Conflicting Interests}

The author(s) declared no potential conflicts of interest with respect to the research, authorship, and/or publication of this article.

\section{Funding}

The author(s) received no financial support for the research, authorship, and/or publication of this article. 